\title{
Use of TEM-EDX for structural formula identification of clay minerals: a case study of Di Linh bentonite, Vietnam
}

Thao Hoang-Minh, Jörn Kasbohm, Lan Nguyen-Thanh, Pham Thi Nga, Le Thi Lai, Nguyen Thuy Duong, Nguyen Duc Thanh, Nguyen Thi Minh Thuyet, Dao Duy Anh, Roland Pusch, Sven Knutsson and Rafael Ferreiro Mählmann

J. Appl. Cryst. (2019). 52, 133-147

\section{IU IUCr Journals CRYSTALLOGRAPHY JOURNALS ONLINE \\ Copyright (C) International Union of Crystallography \\ Author(s) of this paper may load this reprint on their own web site or institutional repository provided that this cover page is retained. Republication of this article or its storage in electronic databases other than as specified above is not permitted without prior permission in writing from the IUCr. \\ For further information see http://journals.iucr.org/services/authorrights.html}


JOURNAL OF

APPLIED

CRYSTALLOGRAPHY

ISSN 1600-5767

Received 16 July 2018

Accepted 21 December 2018

Edited by J. M. García-Ruiz, Instituto Andaluz de Ciencias de la Tierra, Granada, Spain

Keywords: clay minerals; Di Linh bentonite; transmission electron microscopy; energydispersive X-ray spectroscopy; structural formulae.

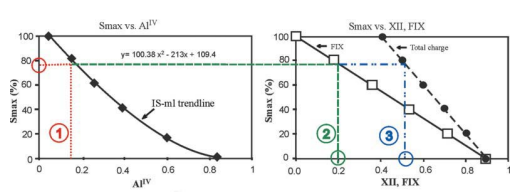

C 2019 International Union of Crystallography

\section{Use of TEM-EDX for structural formula identification of clay minerals: a case study of Di Linh bentonite, Vietnam}

\author{
Thao Hoang-Minh, ${ }^{\mathrm{a} *}$ Jörn Kasbohm, ${ }^{\mathrm{b}}$ Lan Nguyen-Thanh, ${ }^{\mathrm{c}}$ Pham Thi Nga, ${ }^{\mathrm{a}}$ Le Thi \\ Lai, ${ }^{d}$ Nguyen Thuy Duong, ${ }^{a}$ Nguyen Duc Thanh, ${ }^{\mathrm{e}}$ Nguyen Thi Minh Thuyet, ${ }^{a}$ \\ Dao Duy Anh, ${ }^{\text {f }}$ Roland Pusch, ${ }^{\mathrm{g}}$ Sven Knutsson ${ }^{\mathrm{g}}$ and Rafael Ferreiro Mählmann ${ }^{\mathrm{c}}$
}

${ }^{a}$ VNU University of Science, Vietnam National University, Hanoi, Hanoi 10000, Vietnam, ${ }^{\mathbf{b}}$ Jörn-Kasbohm-Consulting and Greifswald University, Greifswald 17487, Germany, 'Institute of Applied Geosciences, Technical University of Darmstadt, Darmstadt 64287, Germany, ${ }^{\mathbf{d}}$ Institute of Geological Sciences, Vietnam Academy of Science and Technology, Hanoi 10000, Vietnam, ${ }^{\mathbf{e}}$ Advance Technology Transfer and Consultancy Co., Hanoi 10000, Vietnam, ${ }^{\mathbf{f}}$ National Institute of Mining - Metallurgy Science and Technology, Hanoi 10000, Vietnam, and ${ }^{\mathbf{g}}$ Luleå University of Technology, Luleå 97187, Sweden. *Correspondence e-mail: hoangminhthao@vnu.edu.vn

Transmission electron microscopy linked with energy-dispersive X-ray spectroscopy (TEM-EDX) was applied to characterize mineralogical signals of weathering processes in the Di Linh bentonite deposit (Vietnam) and to visualize the effects of $\mathrm{Na}$ activation on the smectitic phases. Modelling of X-ray diffraction patterns (oriented mount) was applied in order to refine the computed structural formula. X-ray diffraction, X-ray fluorescence and Fouriertransform infrared spectroscopy (FT-IR) methods were also applied to verify the TEM-EDX results. An Excel-based routine has been developed in this research to allow fast computation of structural formulae and classification of the investigated clay particles. This routine supports the acquirement of 100-300 TEM-EDX analyses as a representative set of individual particles for each sample. The Excel-based routine involves end members of different clay-mineral groups and interstratifications with two or three members (e.g. illite-smectite interstratifications - IS-ml; dioctahedral vermiculite-smectite interstratifications - diVS-ml; and kaolinite-montmorillonite-dioctahedral vermiculite interstratifications - KSV-ml). The routine is now freely available. According to the identification procedure, the $<2 \mu \mathrm{m}$ fraction of the Di Linh bentonite (Vietnam) is composed mainly of $\mathrm{K}$ - and charge-deficient illite-smectite interstratifications (or diVS-ml): montmorillonite-rich randomly ordered (R0) type and illite-rich regularly ordered (R1) type. Additionally, Fe-poor KSV-ml was identified. Industrial $\mathrm{Na}$ activation of the Di Linh bentonite resulted in an increase of the R1 diVS-ml portion and dissolution of a large part of the smectite-rich phases. The TEM-EDX approach also gave analytical proof of a sedimentary process for Di Linh smectite. The parent muscovite was altered in two different environments: (i) K-leaching and layer-wise alteration into kaolinite (weathering), and (ii) further edge-controlled alteration of mica into lath-like montmorillonite particles associated with a dissolution of kaolinite layers from the former kaolinite-mica intergrowths by heat impact (basalt flow).

\section{Introduction}

Clays and clay minerals are widespread in most geological systems. They occur in weathering crusts and soils, continental and marine sediments, volcanic deposits, geothermal fields, altered wallrock produced by the intrusion of plutonic rocks and hydrothermal fluids, and very low grade metamorphic rocks (Galán \& Ferrell, 2013). Clay minerals, especially interstratifications (mixed layer structures), show a high sensitivity in interaction with the surrounding environment. In 
this context, analyses of clay minerals offer specific opportunities to identify traces of their geological history, especially weathering processes.

Transmission electron microscopy (TEM) techniques allow the analysis of individual particles within the same specimen using parameters like morphology, structure (by electron diffraction) and chemical composition. Bain et al. (1994) reviewed microanalysis via several kinds of spectroscopic and chemical determinative methods and concluded that transmission electron microscopy linked with energy-dispersive X-ray spectroscopy (TEM-EDX) is the most appropriate technique to define structural formulae of individual particles of clay minerals. In order to obtain quantitative results, detector calibration (that is, the calibration of $k$ factors according to the Cliff and Lorimer method; Cliff \& Lorimer, 1975; Lorimer \& Cliff, 1976; Mellini \& Menichini, 1985), sample preparation, and knowledge of the sample composition and behaviour under the electron beam are mandatory, because failing to account for these may lead to analytical errors. Further specific issues that sometimes arise include possible precipitation of $\mathrm{Fe}, \mathrm{Al}$ and amorphous silica on clay particles and analysis of overlapping particles (Szymanski et al., 1990; Champness, 1997; Meissner et al., 1998; Drief et al., 2002; Kasbohm et al., 2002; Elsass, 2006; Berthonneau et al., 2014; Pusch et al., 2015; Tamrat et al., 2018; Gaudin et al., 2018). These issues need to be identified and considered.

This study has a particular focus on the application of chemical analysis by TEM-EDX to characterizing tropical weathering and industrial technical processes of Di Linh bentonite (Vietnam). In this report we discuss the processing of a few hundred measured particles per sample by a Microsoft Excel routine that computes the clay mineral structural formula. Fe is commonly precipitated on individual clay mineral particles under humid tropical conditions. This iron component is considered as an additional analytical error in the measured TEM-EDX data set. A combination of TEM-EDX with the modelling of X-ray diffraction (XRD) from oriented specimens with the Sybilla software (developed by Chevron Inc.; Aplin et al., 2006) is used here to verify and to refine the computing of structural formulae from TEM-EDX data.

The TEM-EDX measurement of a few hundred clay mineral particles per sample for the calculation of structural formulae is normally very time consuming and so is often not standard practice for this TEM-EDX methodology. Only a few studies in which the authors measured at least 40-100 particles per sample have been reported (Szymanski et al., 1990; Berthonneau et al., 2014; Tamrat et al., 2018). An analysis of crystal chemistry by applying TEM-EDX-based calculations and modelling of XRD patterns (using oriented specimens) was published by Berthonneau et al. (2014). These authors applied a full-profile modelling of the $00 \ell$ reflections and a multi-specimen approach (Drits et al., 1997; Sakharov et al., 1999).

\section{Geological setting and material}

The Di Linh bentonite is of sedimentary origin and is extracted from the bentonite-, diatomite- and lignite-bearing Di Linh Formation $\left(\mathrm{N}_{1}^{3}-\mathrm{N}_{2}^{1} d l\right)$ in Lam Dong Province, southern Vietnam (Fig. 1). The Di Linh Formation has been regarded as lacustrine sediments, interbedded with two layers of basalt, and being of Upper Miocene-Lower Pliocene age (DGM, 1999). Basalts of Pliocene-Quaternary age were formed in an extensional crustal setting on top of a mantle plume. Because of late exhumation tectonics, the extensional basin was inverted, so erosion and weathering processes dominated. The total thickness of the Di Linh Formation is about one to two hundred metres. In most boreholes, the basal beds of the Di Linh Formation lie unconformably upon Middle Jurassic sediments of the La Nga Formation, Upper Jurassic andesite of the Deo Bao Loc Formation and granitoids of the Late Jurassic Dinh Quan Complex. Basalt of the

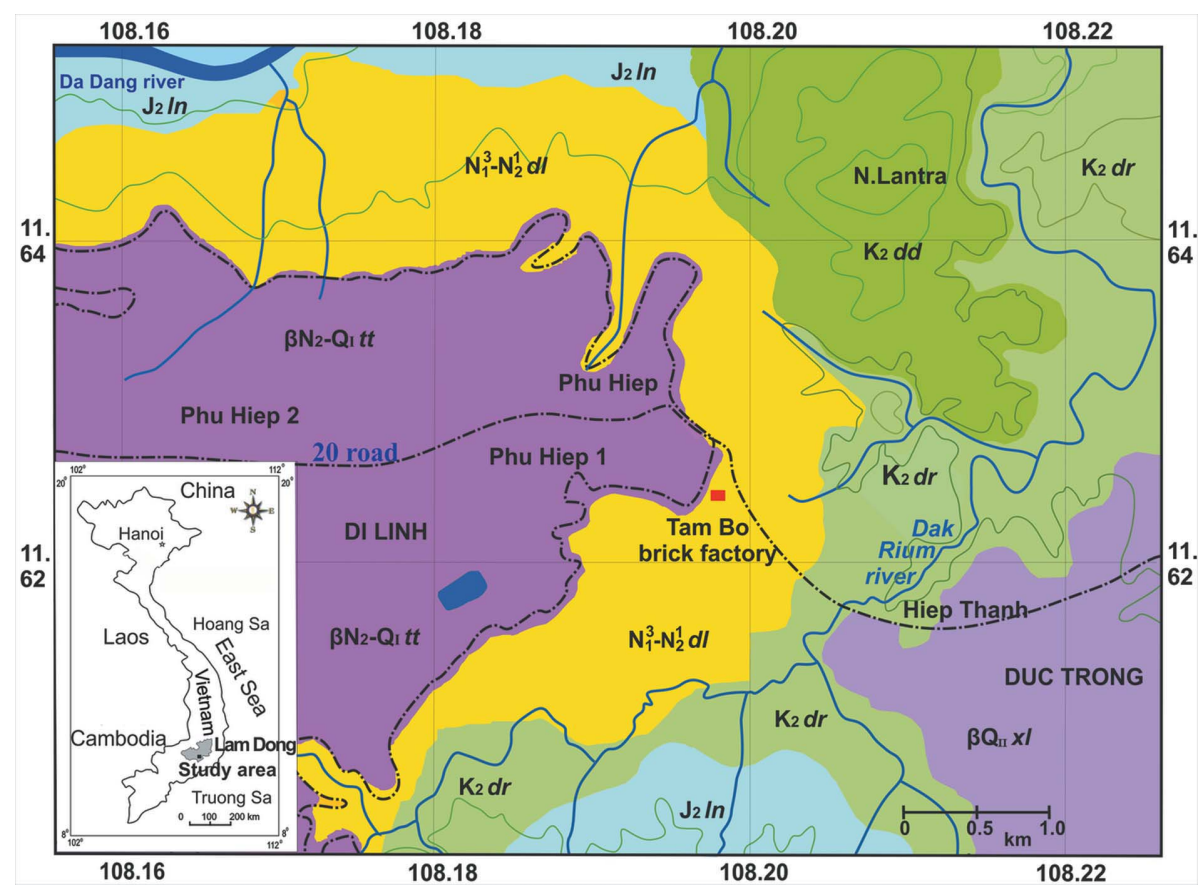

Figure 1

Geological map of Di Linh bentonite area, Lam Dong Province (adapted from Hai, 1979; Huy, 1982). Legend: $\beta \mathrm{Q}_{\mathrm{II}} x l$ - Pleistocene, Quaternary - Xuan Loc Formation - alkaline olivine basalt, hyalobasalt; $\beta \mathrm{N}_{2} \mathrm{Q}_{\mathrm{I}} t t$ - Pliocene, Neogene-Pleistocene, Quaternary - Tuc Trung Formation alkaline olivine basalt, tholelitic basalt, plagiobasalt; $\mathrm{N}^{3}{ }_{1}-\mathrm{N}_{2}^{1} d l$ - Neogene - Di Linh Formation conglomerate, sandstone, argillite, bentonite, lignite, basalt; $\mathrm{K}_{2} d d$ - Upper Cretaceous - Don Duong Formation - dacite, rhyodacite, rhyolite, andesite and their tuff; $\mathrm{K}_{2} d r$ - Upper Cretaceous - Dak Rium Formation - conglomerate, sandstone, red-brown siltstone; $\mathrm{J}_{2} \ln$ - Middle Jurassic - La Nga Formation - sandstone, siltstone, shale, hornfels; solid lines - river, stream; dashed lines - road. 
Di Linh Formation gives two isotopic ages of $9.38 \pm 0.4$ and $13.1 \pm 0.6 \mathrm{Ma}$ (DGM, 1999).

According to analysis of materials extracted by drilling, the Di Linh Formation is composed of eight members (Huy, 1982), among which the composition of a productive layer (Member 6 ) is as follows (in descending order): (1) tile and brick clay (2.6-10 m thick); (2) bentonite with montmorillonite as the main constituent and small amounts of kaolinite and illite. The material in this layer is white-grey, green-grey and in some places yellow-brown in colour. The thickness changes from 5 to $14 \mathrm{~m}$. The Di Linh bentonite from this layer was explored.

Five tons of raw materials (milled to $<5 \mathrm{~mm}$ ) of the Di Linh bentonite mined by Hiep Phu Joint-Stock Company, HJC (Gia Hiep town, Di Linh district, Lam Dong Province) was collected, homogenized and stored in plastic bags for this research. This large amount of material was considered as a possible reference material for further investigations on bentonites in Vietnam. Additionally, the Hiep Phu Joint-Stock Company offered $20 \mathrm{~kg}$ of its trade-ware 'HP600: API'. This product is an industrial $\mathrm{Na}$-activated material derived from the Di Linh bentonite.

\section{Equipment and sample preparation}

3.1. Transmission electron microscopy linked with energydispersive X-ray spectroscopy

The samples were suspended in deionized water and dispersed by ultrasonic treatment for approximately $20 \mathrm{~min}$. The clay fraction $(<2 \mu \mathrm{m})$ was separated by sedimentation and diluted with deionized water to get a clear suspension. The suspension was dropped onto carbon-coated $\mathrm{Cu}$ grids, air dried and stored under environment-controlled conditions at $45 \%$ humidity.

TEM-EDX investigations were carried out on the $<2 \mu \mathrm{m}$ fraction using a FEI TECNAI $G^{2} 20$ electron transmission microscope at the VNU University of Science, Vietnam National University, Hanoi. This equipment (operated at $200 \mathrm{kV}$ with an $\mathrm{LaB}_{6}$ cathode) was combined with an S-TWIN objective, a windowless EDAX energy-dispersive X-ray system and a FEI Eagle 2k CCD TEM camera.

About 200 individual clay particles per sample were characterized by TEM-EDX with respect to crystal size, crystal habit, particle morphology, element distribution and stack order of particles. The crystal size, crystal habit and particle morphology were described according to Henning \& Störr (1986).

For the quantification of element distribution, a calibration of $k$ factors is mandatory (Cliff \& Lorimer, 1975; Lorimer \& Cliff, 1976; Mellini \& Menichini, 1985). These $k$ values are used to calibrate for the specific behaviour of particles against possible irradiation damage. The elements $\mathrm{O}, \mathrm{Na}, \mathrm{Mg}, \mathrm{Al}, \mathrm{Si}$, $\mathrm{K}$, $\mathrm{Ca}$ and $\mathrm{Fe}$ were quantified by applying the EDAX GENESIS-TEM Quant Materials quantification procedure. In this procedure, the acquired EDX spectra are corrected by background subtraction, Gaussian deconvolution and $k$-factor corrections using values previously determined on a phyllo- silicate standard (muscovite) and selected non-phyllosilicate standards. The average errors in the analysed elements using the phyllosilicate standard, expressed as the atomic proportions, are $10(\mathrm{Na}), 5(\mathrm{Fe}, \mathrm{Mg}, \mathrm{K}, \mathrm{Ti}, \mathrm{Ca})$ and $1(\mathrm{Si}, \mathrm{Al})$.

The measurement time per particle was lowered to $20 \mathrm{~s}$ and the exposed area was limited to a $50 \mathrm{~nm}$ diameter, avoiding possible irradiation damage of particles. The stability of particles of the sample series was tested for this measurement time at the beginning of any measurement campaign.

The stack order of particles can be determined by the selected area electron diffraction (SAED) technique. Ringlike structures of the diffracted beam indicate a turbostratic order of the clay layers. Phases with $2 M_{1}$ polytype and $1 M$ polytype for $2: 1$ sheet silicate were characterized by Zöller (1993) on the basis of the relative intensities of (110) and (020) interference in the convergent beam system. The $2 M_{1}$ polytype is indicated by $|110| /|020|>1$ and the $1 M$ polytype by $|110| /|020|<1$.

\subsection{X-ray diffraction}

The XRD analyses were performed on oriented samples of $<2 \mu \mathrm{m}$ material (separated by sedimentation) in air-dried and ethylene glycol-solvated specimens for identification of expandable clay minerals. The specimens were analysed by using a SIEMENS Theta/2Theta D5000 goniometer equipped with a $\mathrm{Cu}$ tube ( $K \alpha_{1,2}$ radiation) and a secondary monochromator (fixed divergence slide: $0.2 \mathrm{~mm}$; collimator: 0.2 ; receiving slit size: $0.1 \mathrm{~mm}$; step size: $0.02^{\circ} 2 \theta$; scan step time: $1 \mathrm{~s}$; measured interval: $3.0-35.0^{\circ} 2 \theta$ ) at the clay laboratory, Technical University Darmstadt. Obtained XRD patterns were modelled with the Sybilla software developed by Chevron Inc. (Aplin et al., 2006), which is a program to compare the measured X-ray diffractogram with a modelled pattern of the basal reflections to better determine discrete clay minerals and interstratifications. The quantities of interlayer ion species and octahedral Fe as well as the mean value of coherent scattering domain sizes $\left(T_{\text {mean }}\right)$ were considered as variables in the fitting process. In particular, this modelling of oriented XRD patterns was applied to validate the TEM-EDX measurements concerning possible precipitations of $\mathrm{Fe}, \mathrm{Al}$ or amorphous silica on particles.

Additionally, bulk samples of the Di Linh clays were analysed by XRD to determine their general mineral composition. The bulk samples were ground in an agate mortar by hand to $<32 \mu \mathrm{m}$ for XRD investigation using a Philips X-ray diffractometer (PW 1710 diffractometer control, PW 1830 generator, PW 3020 vertical goniometer) equipped with a $\mathrm{Cu}$ tube $\left(K \alpha_{1,2}\right.$ radiation $)$ and a secondary monochromator at the Clay Lab, Technical University Darmstadt. The diffractometer operated at a current of $30 \mathrm{~mA}$ and a voltage of $40 \mathrm{kV}$ (variable divergence slit; collimator: 0.2; receiving slit size: $0.05 \mathrm{~mm}$; irradiated length: $10 \mathrm{~mm}$; measured interval: $3.0-70.0^{\circ} 2 \theta$; measurement step: $0.02^{\circ} 2 \theta$; scan step time: $2 \mathrm{~s}$ ). The processing of XRD powder patterns included also Rietveld refinement for semi-quantitative determination of essential mineral components by using the 
Table 1

General schema for the structural formula identification based on TEM-EDX analyses.

According to Köster (1977), adopted by Kasbohm et al. (2002).

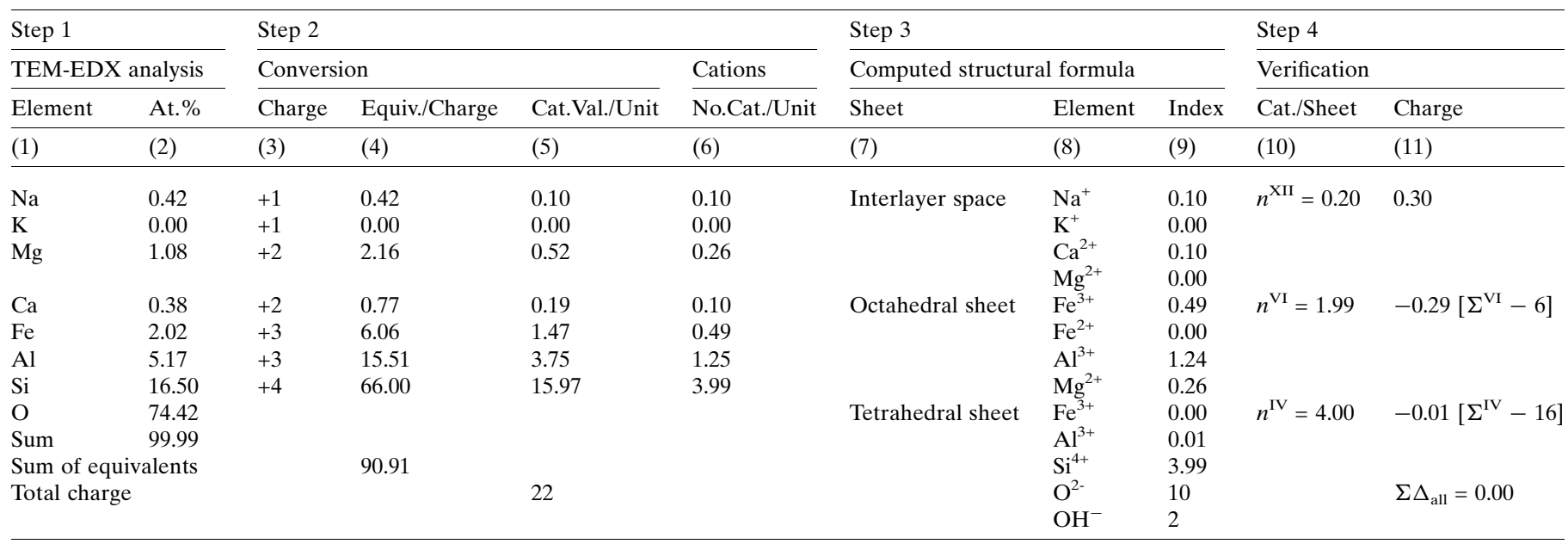

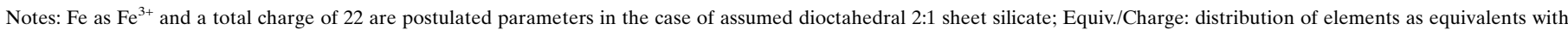

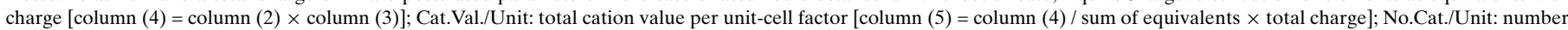

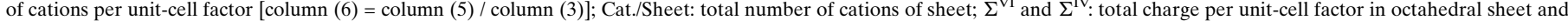

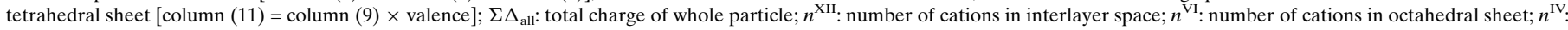
number of cations in tetrahedral sheet.

PROFEX software package (Doebelin \& Kleeberg, 2015) as a graphical interface, which has embedded the $B G M N$ software package (Bergmann et al., 1998; Ufer et al., 2004, 2008).

\subsection{X-ray fluorescence spectroscopy}

The chemical composition of the Di Linh bentonite was analysed by the X-ray fluorescence (XRF) method at the XRF laboratory, VNU University of Science, Vietnam National University, Hanoi. The bulk samples were milled to $<63 \mu \mathrm{m}$ and dried at $313 \mathrm{~K}$ before measurement. Analyses were carried out on $\mathrm{KBr}$ pressed pellets using a wavelengthdispersive Shimadzu XRF-1800 X-ray spectrometer (10 mA current and $20 \mathrm{kV}$ voltage). The XRF results were also used to cross-check the results of Rietveld refinement by the $B G M N$ software.

\subsection{Fourier-transform infrared spectroscopy}

The bulk samples of approximately 1-2 mg were milled, wet sieved to $<40 \mu \mathrm{m}$ and dispersed in $120 \mathrm{mg}$ of $\mathrm{KBr}$, and then the mixtures were pressed to form pellets of $13 \mathrm{~mm}$ in diameter. The analyses were recorded in the mid-infrared range (400$4000 \mathrm{~cm}^{-1}$ ) using a Varian 670 -IR series Fourier-transform infrared (FT-IR) spectrometer (64 scans, $4 \mathrm{~cm}^{-1}$ resolution, room temperature) at the FT-IR laboratory, Technical University Darmstadt. The FT-IR spectra were deconvoluted by the OriginPro peak-fitting technique (OriginLab Corporation). Interpretation of individual bands followed Farmer \& Russell (1964), Farmer (1974), Goodman et al. (1976), Crâciun (1984), Madejová \& Komadel (2001) and Madejová et al. (1994).

\section{Structural formula derivation of clay minerals by TEM-EDX}

\subsection{General procedure}

Identification of the structural formulae from the EDX analyses was carried out in accordance with the procedure introduced by Köster (1977), who proposed the use of equivalent charges and the total charge to determine the atom numbers in the structural formula. The total charge of 2:1 sheet silicate is 22 , representing a half formula unit per $(\mathrm{OH})_{2} \mathrm{O}_{10}$, whilst the total charge of $1: 1$ sheet silicate is 28 , representing a double formula unit per $(\mathrm{OH})_{8} \mathrm{O}_{10}$.

An Excel-based software tool was developed and used to convert the results of EDX analysis (in at.\%) into numbers of cations per unit cell (Table 1). The computed structural formulae in the tetrahedral sheet are predefined by constraining the sum of cations to be four per $(\mathrm{OH})_{2} \mathrm{O}_{10}$. The $\mathrm{Fe}$ content measured by TEM-EDX was postulated to represent $\mathrm{Fe}^{3+}$ valences of dioctahedral clay minerals, or $\mathrm{Fe}^{2+}$ cations of trioctahedral clay minerals. The distribution of $\mathrm{Mg}$ was assumed to fit different structural constitutions because this atom can occur in the octahedral sheet as well as in the interlayer space. The numbers of cations in the octahedral sheet $\left(n^{\mathrm{VI}}\right)$ and interlayer space $\left(n^{\mathrm{XII}}\right)$ offer two additional parameters to demonstrate the plausibility of the structural formulae (Table 1). Furthermore, the sum of the interlayer charge compensates all charge deficits in the octahedral and tetrahedral sheets (Table 1). Such calculations have been applied previously by Kasbohm and his group (Kasbohm et al., 2002; Herbert et al., 2004, 2008, 2011; Nguyen-Thanh, 2012; Nguyen-Thanh, Hoang-Minh et al., 2014; Nguyen-Thanh, Herbert et al., 2014; Hoang-Minh et al., 2014; Nguyen-Thanh et al., 2017). 
Table 2

Matrix of coefficients for interpretation of the structural formulae of end members for certain species of 1:1 and 2:1 layers of sheet silicates (calculated from TEM-EDX analyses).

\begin{tabular}{|c|c|c|c|c|c|c|c|c|c|c|}
\hline \multirow[b]{2}{*}{ Mineral } & \multirow[b]{2}{*}{ tc } & \multicolumn{2}{|l|}{ XII } & \multicolumn{2}{|l|}{$n^{\mathrm{VI}}$} & \multicolumn{2}{|l|}{$\mathrm{Si}^{\mathrm{IV}}$} & \multicolumn{2}{|l|}{$\mathrm{K}^{+}$} & \multirow[b]{2}{*}{ Octahedral sheet } \\
\hline & & Max & Min & Max & Min & Max & Min & $\operatorname{Max}$ & Min & \\
\hline \multicolumn{11}{|l|}{ 1:1 sheet silicates } \\
\hline Kaolinite & 28 & 0.05 & 0.00 & 4.05 & 3.95 & 4.10 & 3.95 & 0.05 & 0.00 & $R^{2+} 0 \pm 0.15 ; R^{3+} 4 \pm 0.15$ \\
\hline Cronstedtite & 28 & 0.05 & 0.00 & 6.05 & 5.85 & 2.15 & 1.85 & 0.00 & 0.00 & $R^{2+} 4 \pm 0.15 ; R^{3+} 2 \pm 0.15$ \\
\hline Berthierine & 28 & 0.05 & 0.00 & 6.05 & 5.85 & 3.15 & 2.85 & 0.00 & 0.00 & $R^{2+} 5 \pm 0.15 ; R^{3+} 1 \pm 0.15$ \\
\hline Chrysotile, lizardite & 28 & 0.05 & 0.00 & 6.05 & 5.85 & 4.10 & 3.85 & 0.00 & 0.00 & $R^{2+} 6 \pm 0.15 ; R^{3+} 0 \pm 0.15$ \\
\hline \multicolumn{11}{|l|}{$2: 1$ sheet silicates } \\
\hline Talc & 22 & 0.05 & 0.00 & 3.00 & 2.90 & 4.00 & 3.90 & 0.02 & 0.00 & \\
\hline Illite & 22 & 1.00 & 0.85 & 2.00 & 1.90 & 3.22 & 2.80 & 1.00 & 0.85 & \\
\hline Di-vermiculite & 22 & 1.00 & 0.70 & 2.03 & 1.95 & 3.30 & 2.80 & 0.80 & 0.00 & \\
\hline Tri-vermiculite & 22 & 0.90 & 0.60 & 3.05 & 2.90 & 2.95 & 2.60 & 0.90 & 0.30 & \\
\hline Montmorillonite & 22 & 0.45 & 0.15 & 2.02 & 1.98 & 4.00 & 3.93 & & & \\
\hline Beidellite & 22 & 0.50 & 0.30 & 2.10 & 1.98 & 3.60 & 3.40 & 0.01 & 0.00 & $\mathrm{Al}^{3+}>1.85$ \\
\hline Nontronite & 22 & 0.55 & 0.30 & 2.10 & 1.98 & 3.60 & 3.40 & 0.01 & 0.00 & $\mathrm{R}^{3+}>1.85 ; \mathrm{Fe}^{3+}>\mathrm{Al}$ \\
\hline Saponite & 22 & 0.55 & 0.25 & 3.00 & 2.70 & 3.75 & 3.30 & & & \\
\hline Chlorite* & 28 & 0.05 & 0.00 & 6.05 & 3.95 & 3.00 & 2.30 & 0.05 & 0.00 & \\
\hline Palygorskite & 21 & 0.15 & 0.00 & 2.50 & 2.20 & 4.00 & 3.75 & 0.15 & 0.00 & $\mathrm{R}^{2+}>\mathrm{R}^{3+}$ \\
\hline
\end{tabular}

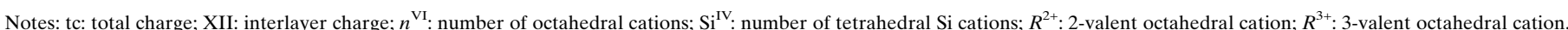

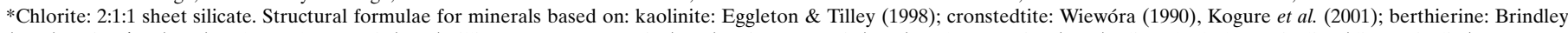

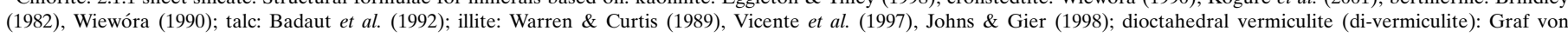

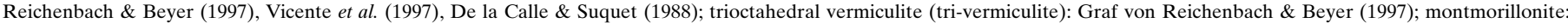

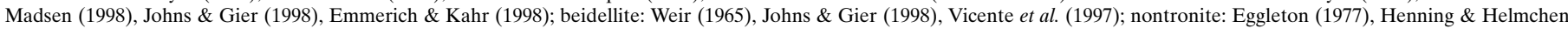

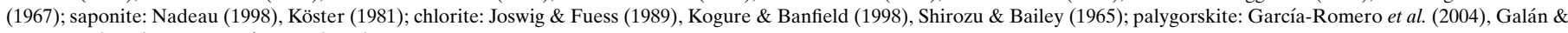
Carretero (1999), Torres-Ruíz et al. (1994).

The computed structural formulae (Table 1) have been transformed into the framework of international classification schemes for theoretical formulae of clay minerals as outlined by Newman \& Brown (1987), Meunier \& Velde (1989), Wiewóra (1990), Moore \& Reynolds (1997), Rieder et al. (1998) and Rosenberg (2002). Additionally, the matrix of specific coefficients with a certain empirical formula range was obtained from these and other published sources (Table 2). This matrix was applied to both 1:1 and 2:1 sheet silicates.

\subsection{Structural formula derivation of interstratifications with} two members

Random interstratifications between illite and montmorillonite (IS-ml) are common components of clay mineral matter. Środoń et al. (1992) suggested further constraints for identification of IS-ml, implying the use of a set of equations for quantifying the proportion of illite and smectite in IS-ml. The main principle was a relationship between the number of 'fixed' $\mathrm{K}$ cations in the interlayer of illite (FIX) and the expandability or the probability (\%) of montmorillonite layers in IS-ml phases ( $\left.\% \mathrm{~S}_{\mathrm{MAX}}\right)$ :

$$
\% \mathrm{~S}_{\mathrm{MAX}}=95.6-105.75 \times \text { FIX } .
$$

The end members postulated by these authors have the interlayer charge values 0.4 for smectite and 0.89 for illite per $(\mathrm{OH})_{2} \mathrm{O}_{10}$ :

$$
\mathrm{XII}=\left[0.89\left(100-\% S_{\mathrm{MAX}}\right)+0.4 \% S_{\mathrm{MAX}}\right] / 100,
$$

where XII is the interlayer charge. On the basis of the IS-ml data published by these authors, $\% \mathrm{~S}_{\mathrm{MAX}}$ was also used to calculate the amount of tetrahedrally coordinated $\mathrm{Al}\left(\mathrm{Al}^{\mathrm{IV}}\right)$ :

$$
\% \mathrm{~S}_{\mathrm{MAX}}=100.38\left(\mathrm{Al}^{\mathrm{IV}}\right)^{2}-213\left(\mathrm{Al}^{\mathrm{IV}}\right)+109.4 .
$$

Finally, the calculated structural formula has to fit the principle of total charge as described by Köster (1977).

The Japanese Kunipia F bentonite (a commercial product of Kunimine Industry Co. Ltd) was also available for testing purposes. The averaged structural formula of nearly 30 particles has shown a good agreement (Table 3) with earlier data published by Wilson et al. (2011). Using the equations of Środon et al. (1992), the Kunipia F bentonite was found to contain K-deficient illite-smectite interstratifications, because the measured $\mathrm{K}$ content of 0.03 per $(\mathrm{OH})_{2} \mathrm{O}_{10}$ is lower than the required FIX value of 0.20 . Fig. 2 is a graphic showing the calculation procedure and verifying that this IS-ml phase is composed of interstratifications of $78 \%$ montmorillonitic layers and $22 \%$ illitic layers. K- and/or charge-deficient IS-ml is denoted in this report as dioctahedral vermiculite-smectite (diVS-ml) interstratifications. In this manner, the proposed equations and structural formulae obtained by TEM-EDX analyses can be used to characterize the interstratifications.

\subsection{Structural formula derivation of interstratifications with} three members

Random interstratifications with more than two components can also occur in a clay mineral material. Interstratifications between illite, dioctahedral vermiculite and smectite as well as between kaolinite, illite and dioctahedral vermiculite have been found in sediments from the North Sea by a complex XRD procedure (e.g. Drits et al., 1997; Sakharov et al., 1999). Hong et al. (2015) characterized random interstratifications of illite, smectite and kaolinite in hydromorphic 
Table 3

Structural formula of Kunipia $F$ bentonite: example for TEM-EDX results in comparison to literature data.

\begin{tabular}{|c|c|c|c|}
\hline \multirow[t]{2}{*}{ Element } & \multicolumn{2}{|c|}{ Our TEM-EDX measurement $(n=28)$} & \multirow[t]{2}{*}{ Wilson et al. (2011) } \\
\hline & Weight $(\%)$ & SDOM (\%) & \\
\hline $\mathrm{O}$ & 71.3 & \pm 0.54 & \\
\hline $\mathrm{Na}$ & 2.7 & \pm 0.18 & \\
\hline $\mathrm{Mg}$ & 1.6 & \pm 0.05 & \\
\hline $\mathrm{Al}$ & 7.2 & \pm 0.21 & \\
\hline $\mathrm{Si}$ & 16.1 & \pm 0.41 & \\
\hline $\mathrm{P}$ & 0.1 & \pm 0.01 & \\
\hline $\mathrm{S}$ & 0.2 & \pm 0.04 & \\
\hline $\mathrm{Cl}$ & 0.1 & \pm 0.01 & \\
\hline K & 0.1 & \pm 0.06 & \\
\hline $\mathrm{Ca}$ & 0.3 & \pm 0.04 & \\
\hline $\mathrm{Fe}$ & 0.3 & \pm 0.03 & \\
\hline \multicolumn{4}{|c|}{ Structural formula } \\
\hline \multicolumn{4}{|c|}{ Interlayer space } \\
\hline $\mathrm{Ca}^{2+}$ & 0.01 & \pm 0.00 & 0.03 \\
\hline $\mathrm{Mg}^{2+}$ & 0.01 & \pm 0.00 & 0.01 \\
\hline $\mathrm{Na}^{+}$ & 0.48 & \pm 0.02 & 0.48 \\
\hline $\mathrm{K}^{+}$ & 0.03 & \pm 0.01 & 0.01 \\
\hline \multicolumn{4}{|c|}{ Octahedral sheet } \\
\hline $\mathrm{Al}^{3+}$ & 1.55 & \pm 0.01 & 1.54 \\
\hline $\mathrm{Fe}^{3+}$ & 0.07 & \pm 0.01 & 0.09 \\
\hline $\mathrm{Fe}^{2+}$ & & & 0.02 \\
\hline $\mathrm{Mg}^{2+}$ & 0.37 & \pm 0.01 & 0.35 \\
\hline$n^{\mathrm{VI}}$ & 2.00 & \pm 0.00 & 2.00 \\
\hline \multicolumn{4}{|c|}{ Tetrahedral sheet } \\
\hline $\mathrm{Al}^{3+}$ & 0.16 & \pm 0.01 & 0.13 \\
\hline $\mathrm{Si}^{4+}$ & 3.84 & \pm 0.01 & 3.87 \\
\hline$\% \mathrm{~S}$ & $78 \%$ & \pm 2.00 & $83 \%$ \\
\hline \multicolumn{4}{|l|}{ Charges } \\
\hline XII & 0.54 & \pm 0.02 & 0.57 \\
\hline VI & -0.38 & \pm 0.06 & -0.37 \\
\hline IV & -0.16 & \pm 0.07 & -0.13 \\
\hline
\end{tabular}

Notes: $n$ : number of measured particles; SDOM: standard deviation of the mean; $n^{\mathrm{VI}}$. number of octahedral cations; \%S: smectitic layer probability; XII: interlayer charge; VI: octahedral charge; IV: tetrahedral charge.

soils in southern China and identified these phases by XRD and by using lattice fringes from high-resolution transmission electron microscopy (HR-TEM). The authors concluded that
Table 4

Setting of starting coefficients for calculation of structural formulae for interstratifications with three members (per $\mathrm{OH}_{2} \mathrm{O}_{10}$ or per $\mathrm{OH}_{8} \mathrm{O}_{10}$ ).

\begin{tabular}{lccccc}
\hline Mineral & Total charge & $\mathrm{XII}$ & $n^{\mathrm{VI}}$ & $\mathrm{Si}^{\mathrm{IV}}$ & $(\mathrm{OH})$ \\
\hline \multicolumn{5}{l}{ Kaolinite-smectite-dioctahedral vermiculite interstratifications } \\
Kaolinite & 28 & 0 & 4 & 4 & 8 \\
Montmorillonite & 22 & 0.15 & 2 & 4 & 2 \\
Dioctahedral vermiculite & 22 & 0.70 & 2 & 3.3 & 2 \\
\multicolumn{7}{l}{} \\
Chlorite-saponite-trioctahedral vermiculite interstratifications (CSV-ml) \\
Chlorite & 28 & 0 & $5,5.6,6$ & 2.75 & 8 \\
Saponite & 22 & 0.35 & 2.7 & 3.7 & 2 \\
Trioctahedral vermiculite & 22 & 0.90 & 3 & 2.7 & 2 \\
\hline
\end{tabular}

Notes: XII: interlayer charge; $\mathrm{Si}^{\mathrm{IV}}$ : number of tetrahedral Si cations; $n^{\mathrm{VI}}$ : number of octahedral cations; $(\mathrm{OH})_{n}$ : number of hydroxyl groups.

hydromorphic conditions in Xuancheng led simultaneously to the direct transformation of illite to kaolinite and the transformation of illite to smectite to kaolinite in the pedogenic processes, so that the interstratifications with the three members were formed as an intermediate product.

A mathematical procedure using TEM-EDX data was developed to compute the structural formulae and ratios of the components in possible three-component interstratifications, e.g. kaolinite-montmorillonite-dioctahedral vermiculite interstratifications (KSV-ml), chlorite-saponite-trioctahedral vermiculite interstratifications (CSV-ml) and talc-saponitetrioctahedral vermiculite interstratifications (TSV-ml). The TEM-EDX procedure does not offer any opportunity to distinguish between fixed $\mathrm{K}$ and exchangeable $\mathrm{K}$ determined in mica-like structures. Therefore, the dioctahedral mica-like component was treated in the TEM-EDX procedure as dioctahedral vermiculite, which was considered a structural precursor for illite.

A procedure for the determination of the ratio of the three layer types (e.g. in $\mathrm{KSV}-\mathrm{ml}, \% \mathrm{~K}, \% \mathrm{~S}, \% \mathrm{~V})$ was introduced by Nguyen-Thanh et al. (2010) and Herbert et al. (2011). The starting point of the calculation is the computing of the structural formulae ( $c f$. Table 1), where $\mathrm{Fe}$ was postulated to be $\mathrm{Fe}^{3+}$ cations for computation of KSV-ml. The calculation of

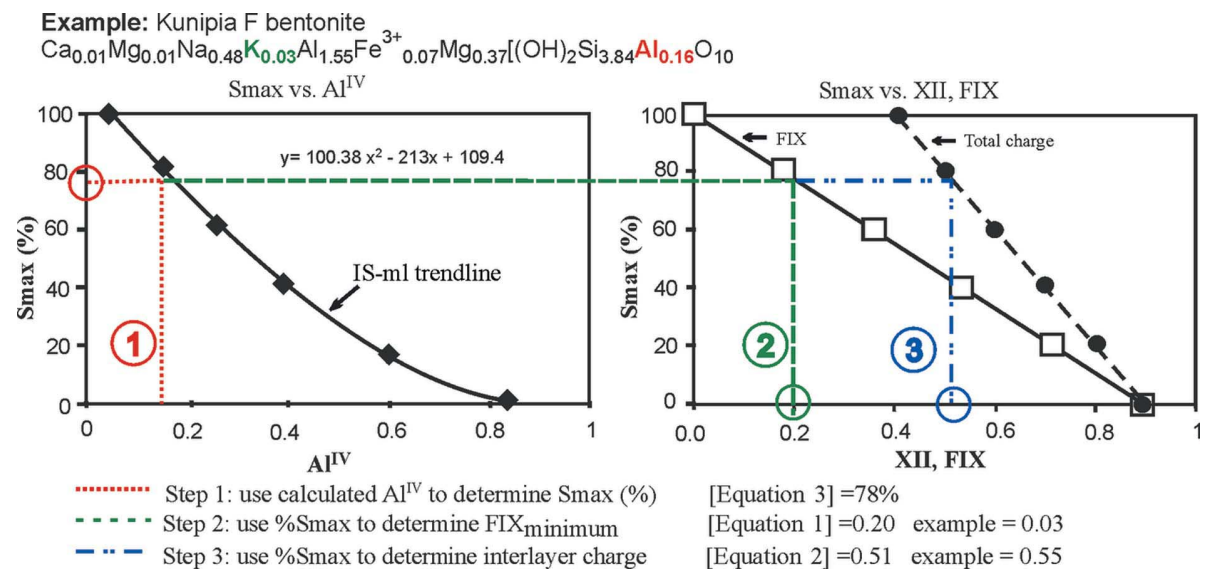

Figure 2

Graphical verification of IS-ml composition following the method of Środon et al. (1992); case study of Kunipia F bentonite. Notes: $\mathrm{Al}^{\mathrm{IV}}$ : octahedral $\mathrm{Al}$; XII: interlayer charge; FIX: 'fixed' $\mathrm{K}$ in illite; \% $\mathrm{S}_{\mathrm{MAX}}$ : ratio (\%) of montmorillonitic layers in IS-ml. 
Table 5

Matrix of computed values for three ratios of thee-component interstratifications $(\% \mathrm{~K}, \% \mathrm{~S}, \% \mathrm{~V})$.

\begin{tabular}{|c|c|c|c|c|c|c|c|c|c|c|}
\hline \multirow{2}{*}{$\begin{array}{l}\text { Total charge } \\
\text { tc }\end{array}$} & \multicolumn{3}{|c|}{ Interval for possible ratios of layers } & \multicolumn{2}{|c|}{ Measured values } & \multicolumn{2}{|c|}{ Computed values } & \multicolumn{3}{|c|}{ Considering different position of $\mathrm{Mg}$} \\
\hline & $\% \mathrm{~K}$ & $\% \mathrm{~S}$ & $\% \mathrm{~V}$ & $n_{\text {meas }}^{\mathrm{VI}}$ & $\mathrm{XII}_{\text {meas }}$ & $n_{\mathrm{mod}}^{\mathrm{VI}}$ & $\mathrm{XII}_{\mathrm{mod}}$ & $\Delta n^{\mathrm{VI}}$ & $\Delta \mathrm{XII} / 2$ & $\Sigma \Delta_{\text {all }}$ \\
\hline (1) & (2) & (3) & (4) & $(5)$ & $(6)$ & (7) & (8) & (9) & (10) & (11) \\
\hline \multicolumn{11}{|l|}{ Range } \\
\hline 22.0 & 0.00 & 0.05 & 0.95 & 2.23 & 0.04 & 2.00 & 0.67 & 0.23 & -0.32 & -0.08 \\
\hline 22.5 & 0.08 & 0.08 & 0.84 & 2.38 & 0.04 & 2.17 & 0.60 & 0.21 & -0.28 & -0.07 \\
\hline 24.0 & 0.33 & 0.15 & 0.51 & 2.80 & 0.04 & 2.67 & 0.38 & 0.13 & -0.17 & -0.04 \\
\hline 24.5 & 0.42 & 0.18 & 0.41 & 2.94 & 0.04 & 2.83 & 0.31 & 0.11 & -0.13 & -0.03 \\
\hline 25.0 & 0.50 & 0.20 & 0.30 & 3.08 & 0.04 & 3.00 & 0.24 & 0.08 & -0.10 & -0.02 \\
\hline 25.5 & 0.58 & 0.23 & 0.19 & 3.23 & 0.04 & 3.17 & 0.17 & 0.06 & -0.06 & 0.00 \\
\hline 26.0 & 0.67 & 0.25 & 0.08 & 3.37 & 0.04 & 3.33 & 0.09 & 0.03 & -0.03 & 0.01 \\
\hline 26.5 & 0.75 & 0.28 & -0.03 & 3.51 & 0.04 & 3.50 & 0.02 & 0.01 & 0.01 & 0.02 \\
\hline 27.0 & 0.83 & 0.30 & -0.14 & 3.65 & 0.05 & 3.67 & -0.05 & -0.02 & 0.05 & 0.03 \\
\hline
\end{tabular}

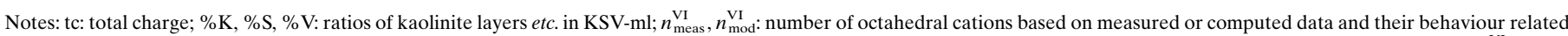

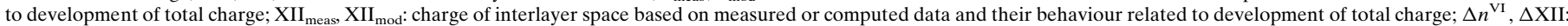

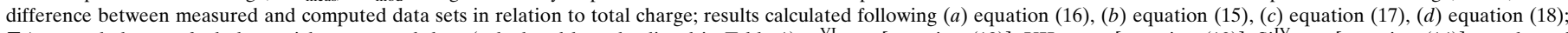

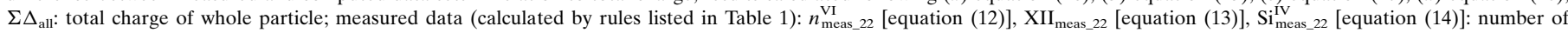
octahedral cations, charge of interlayer space and tetrahedral Si, respectively, at total charge of 22 (calculated from TEM-EDX analysis following rules in Table 1).

such structural formulae uses a matrix of predefined values as starting coefficients for each member of this interstratification series (Table 4): the total charge (tc), the interlayer charge (XII), the number of cations in octahedral positions $\left(n^{\mathrm{VI}}\right)$, the amount of tetrahedral $\mathrm{Si}^{4+}\left(\mathrm{Si}^{\mathrm{IV}}\right)$ and the number of hydroxyl groups $(\mathrm{OH})_{n}$.

The different components of the KSV-ml phase are characterized by using the behaviour of the measured and computed values for the number of atoms in the octahedral sheet $\left(n_{\text {meas }}^{\mathrm{VI}}, n_{\text {mod }}^{\mathrm{VI}}\right)$ and the charge in the interlayer space $\left(\mathrm{XII}_{\text {meas }}, \mathrm{XII}_{\mathrm{mod}}\right)$ in relation to the development of total charge from 22 to 28 (Table 5). The probability of kaolinitic layers $\left(\% \mathrm{~K}_{\mathrm{mod}}\right)$ depends directly on the total charge $\left(\mathrm{tc}_{\mathrm{mod}}\right)$. The development of vermiculitic layers $\left(\% \mathrm{~V}_{\mathrm{mod}}\right)$ is additionally controlled by the measured $\mathrm{Si}$ value (for tc $=22$ ) $\left(\mathrm{Si}_{\text {meas_22 }}^{\mathrm{IV}}\right)$. The rest of the layers in $\mathrm{KSV}$-ml are smectitic layers $\left(\% \mathrm{~S}_{\mathrm{mod}}\right)$. The procedure for determining the components of the CSV-ml phase is similar. The following equations were applied in the derivation of the three components of the $\mathrm{KSV}$-ml phase and further parameters (numeric values in the equations below are taken from Table 4):

Quantitative composition of KSV-ml:

$$
1=\% \mathrm{~K}+\% \mathrm{~S}+\% \mathrm{~V}
$$

Calculation of the parameters using a key parameter model (Table 4):

$$
\begin{gathered}
\mathrm{tc}_{\mathrm{mod}}=28 \% \mathrm{~K}+22 \% \mathrm{~S}+22 \% \mathrm{~V} \\
\mathrm{n}_{\mathrm{mod}}^{\mathrm{VI}}=4 \% \mathrm{~K}+2 \% \mathrm{~S}+2 \% \mathrm{~V}
\end{gathered}
$$

$$
\begin{gathered}
\mathrm{XII}_{\text {mod }}=0.15 \% \mathrm{~S}+0.7 \% \mathrm{~V} \\
\mathrm{Si}_{\text {mod }}^{\mathrm{iV}}=4 \% \mathrm{~K}+4 \% \mathrm{~S}+3.3 \% \mathrm{~V}
\end{gathered}
$$

For each $\mathrm{tc}_{\mathrm{mod}}$, it is possible to calculate $\% \mathrm{~K}, \% \mathrm{~V}$ and $\% \mathrm{~S}$ in the interstratifications:

$$
\% \mathrm{~K}_{\bmod }=\left(\mathrm{tc}_{\bmod }-22\right) /(28-22)
$$

[equation (9) is the result of substituting (4) into (5)]

$$
\begin{gathered}
\% \mathrm{~S}_{\text {mod }}=1-\% \mathrm{~K}_{\text {mod }}-\% \mathrm{~V}_{\text {mod }} \\
\% \mathrm{~V}_{\text {mod }}=\left(4-\mathrm{Si}_{\text {meas_22 }} / 22 \mathrm{tc}_{\text {mod }}\right) /(4-3.3)
\end{gathered}
$$

[as a result of substituting (4) and (14) into (8)]

Calculation of the parameters using measured TEM-EDXdata:

$$
\begin{gathered}
n_{\text {mod }}^{\mathrm{VI}}=\mathrm{tc}_{\text {mod }} / 22\left(n_{\text {meas_22 }}^{\mathrm{VI}}+4\right)-4 \\
\mathrm{XII}_{\text {mod }}=\mathrm{XII}_{\text {meas_22 }} / 22 \mathrm{tc}_{\text {mod }} \\
\mathrm{Si}_{\text {mod }}^{\mathrm{IV}}=\mathrm{Si}_{\text {meas_22 }}^{\mathrm{IV}} / 22 \mathrm{tc}_{\text {mod }}
\end{gathered}
$$

Results (using request $\Delta \mathrm{n}^{\mathrm{VI}}+\Delta \mathrm{XII}=0$ ):

$$
\begin{gathered}
\% \mathrm{~K}_{\mathrm{mod}}=-\Sigma \Delta_{\mathrm{tc}=22} /\left(\Sigma \Delta_{\mathrm{tc}=28}-\Sigma \Delta_{\mathrm{tc}=22}\right), \\
\mathrm{tc}_{\mathrm{mod}}=\% \mathrm{~K}_{\mathrm{mod}}(28-22)+22
\end{gathered}
$$

$$
\% \mathrm{~V}_{\text {mod }}=\left\{4-\mathrm{Si}_{\text {meas_22 }}^{\mathrm{IV}} / 22\left[\% \mathrm{~K}_{\text {mod }}(28-22)+22\right]\right\} /(4-3.3)
$$

$$
\mathrm{oS}_{\mathrm{mod}}=1-\% \mathrm{~K}_{\mathrm{mod}}-\% \mathrm{~V}_{\mathrm{mod}}
$$


Table 6

Example for the derivation of structural formulae for the KSV-ml phase based on TEM-EDX analysis.

According to the schema and rules described in Table 1.

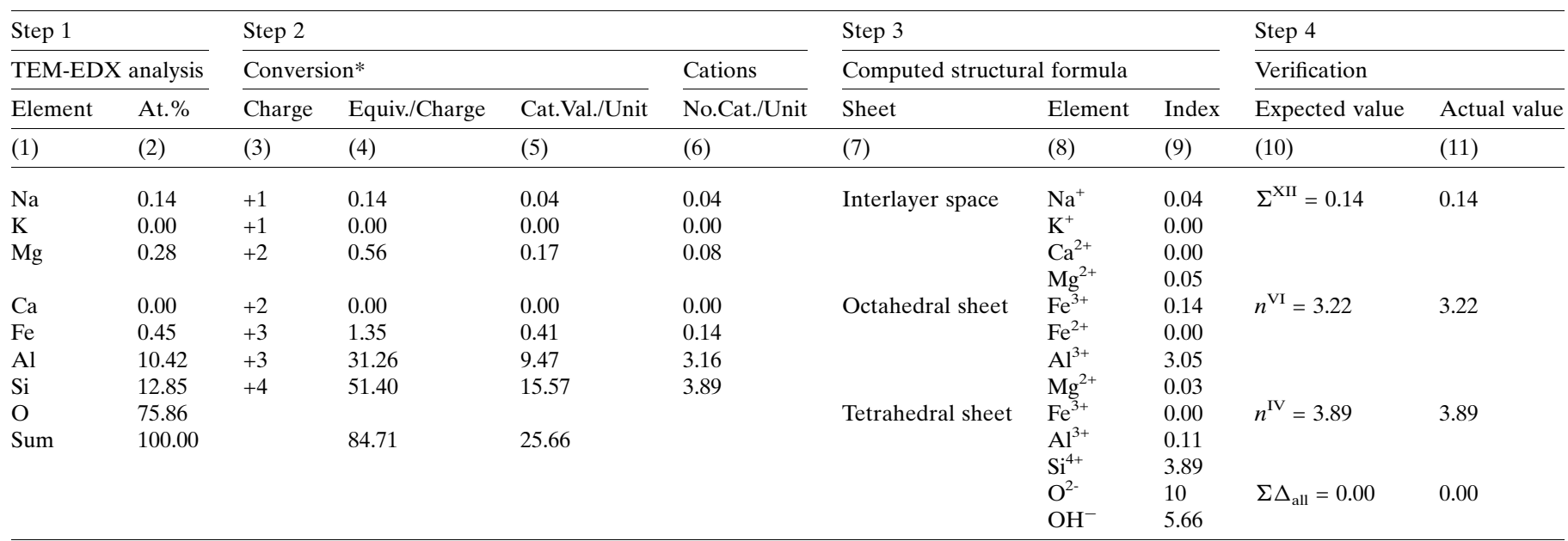

Notes: *according to Köster (1977), adopted by Kasbohm et al. (2002); abbreviations are explained in Table 1; applied TEM-EDX analysis [column (2)] is used also in Table 5.

The percentage of kaolinitic layers also depends on the difference between the development of total charge from 22 $\left(\Sigma \Delta_{\mathrm{tc}=22}\right)$ to $28\left(\Sigma \Delta_{\mathrm{tc}=28}\right)$.

The computing of three ratios of interstratifications with three members lets us determine also the relevant total charge (see example in results of Table 5 : tc $=25.66$ ) for the TEMEDX analysis. The derivation of structural formulae for the considered KSV phase follows again the rules presented in Table 1, but using the mentioned relevant total charge (Table 6).

\section{Structural formula identification of clay minerals for Di Linh bentonite}

\subsection{Mineral composition of bulk samples studied by XRD and} FT-IR

The powder X-ray diffractograms, processed with Rietveld refinement by the $B G M N$ software, of the bulk material from the two samples show a similar mineral composition. The XRF results (not shown) were used to cross-check the results to obtain the lowest errors. Smectite, muscovite, kaolinite and quartz are the main phases; K-feldspar, illite, goethite, lepidocrocite, hematite and rutile occur in traces (Fig. 3 and Table 7). The smectite of the reference bentonite is characterized by bivalent cations in the interlayer space $[1.48 \mathrm{~nm}$ for the (001) interference], and the impact of $\mathrm{Na}$ on the $\mathrm{Na}$ activated material is shown by (001) interference at $1.2 \mathrm{~nm}$ (Fig. 3). Muscovite represents the $2 M_{1}$ polytype and illite the $1 M$ polytype of dioctahedral mica. The amount of muscovite and kaolinite is remarkably different in the two samples. However, quartz has a comparable concentration in the two samples, between 10 and $11 \%$.

The FT-IR absorption spectra of the bentonite samples (Fig. 4) are characterized by double absorption peaks around 3625 and $3420 \mathrm{~cm}^{-1}$, intense peaks around $1032 \mathrm{~cm}^{-1}$, and
Table 7

Mineral composition (\%) of Di Linh bentonite (bulk sample), using Rietveld processing of XRD results by Profex-BGMN.

Including relative standard deviation

\begin{tabular}{lll}
\hline Phase & Reference material & Na-activated material \\
\hline Ca-smectite & $34 \pm 2$ & $4 \pm 14$ \\
Na-smectite & $6 \pm 16$ & $35 \pm 3$ \\
Muscovite & $5 \pm 23$ & $16 \pm 3$ \\
Illite & $2 \pm 13$ & $1 \pm 22$ \\
Kaolinite & $41 \pm 6$ & $28 \pm 4$ \\
Quartz & $10 \pm 1$ & $11 \pm 1$ \\
K-feldspar & $<1$ & $2 \pm 10$ \\
Lepidocrocite & $2 \pm 99$ & $1 \pm 18$ \\
Goethite & $<1$ & $1 \pm 5$ \\
Hematite & - & $<1$ \\
Rutile & $<1$ & $<1$ \\
\hline
\end{tabular}

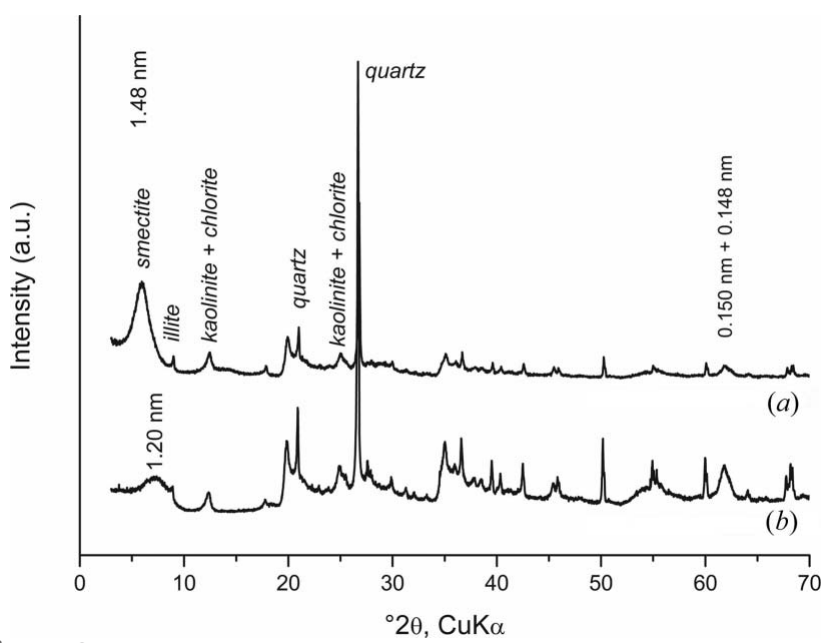

Figure 3

XRD patterns (bulk samples) of Di Linh bentonite: $(a)$ reference material and (b) Na-activated material. 


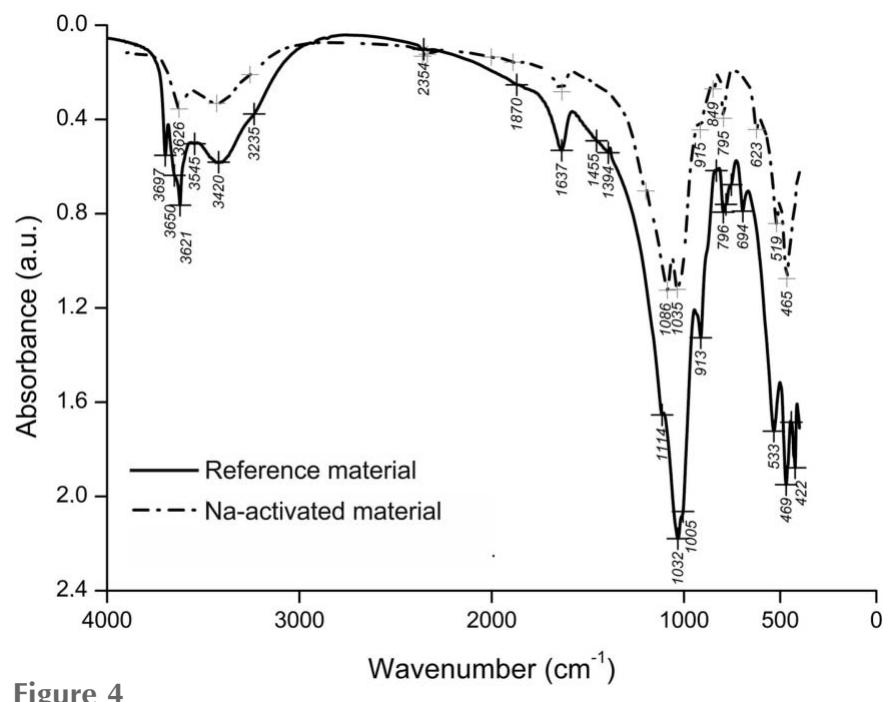

FT-IR spectra (bulk samples) of Di Linh bentonite: solid line - reference material; dot-dashed line - Na-activated material.

weak peaks around 915 and $849 \mathrm{~cm}^{-1}$ (Russell et al., 1970). Furthermore, $\mathrm{SiO}$ bands at about $1040 \mathrm{~cm}^{-1}$ are characteristic of montmorillonite. Sharp doublets at 3696 and $3620 \mathrm{~cm}^{-1}$ are characteristic of the kaolin group in general (Madejová \& Komadel, 2001). Supporting bands at 796 ( $\mathrm{Si}-\mathrm{O})$ and $698 \mathrm{~cm}^{-1}(\mathrm{Si}-\mathrm{O})$ are diagnostic for kaolinite, too. Both types of bands are seen together only in the reference material. The diagnostic bands of quartz were observed at lower intensities at 796 and $778 \mathrm{~cm}^{-1}$. In general, the FT-IR spectrum of the reference bentonite has a higher absorbance intensity than the spectrum of the Na-activated bentonite (Fig. 4).

\subsection{Structural formula identification based on TEM-EDX data}

Regarding morphological forms, most of the $<2 \mu \mathrm{m}$ particles of the Di Linh bentonite samples can be divided into three groups: (i) xenomorphic plates with discrete margins, (ii) cloudy aggregates composed of $<50 \mathrm{~nm}$ broad laths with idiomorphic ends and (iii) xenomorphic film-like particles with rolled-up edges, indicating fully expandable smectite [Fig. 5(a)]. These lath-like particles commonly grew on the edges of the xenomorphic plates [Fig. 5(b)]. A few particles observed with discrete shape and dark-grey colour were identified as oxides and hydroxides of goethite [Fig. 5(c)], anatase and quartz. The chemical compositions of individual particles measured by TEM-EDX were used to calculate structural formulae with the procedures described above (Tables 1 and 8).

5.2.1. Di Linh reference bentonite. One particle of the Di Linh reference bentonite with the chemical composition shown in Table 1 was identified as a normal-charge montmorillonite: $\left[\mathrm{Ca}_{0.10} \mathrm{Na}_{0.10}\right]\left[\mathrm{Al}_{1.24} \mathrm{Fe}^{3+}{ }_{0.49} \mathrm{Mg}_{0.26}(\mathrm{OH})_{2}\right]\left[\mathrm{Si}_{3.99} \mathrm{Al}_{0.01} \mathrm{O}_{10}\right]$. $2 \mathrm{H}_{2} \mathrm{O}$. A similar procedure was applied to all measured particles. The results show that diVS-ml and KSV-ml were the main clay mineral phases in the clay fraction of the Di Linh reference bentonite, with 70 and 14 frequency\% (frequency percentage of occurrence), respectively. IS-ml with 4 frequency $\%, \mathrm{CSV}-\mathrm{ml}$ with 1 frequency $\%$ and goethite with 2 frequency $\%$ were minor and trace phases. The average chemical formula of diVS-ml was identified as $\left[\mathrm{Ca}_{0.05} \mathrm{Mg}_{0.08^{-}}\right.$ $\left.\mathrm{Na}_{0.11} \mathrm{~K}_{0.06}\right]\left[\mathrm{Al}_{1.39} \mathrm{Fe}^{3+}{ }_{0.42} \mathrm{Mg}_{0.19}(\mathrm{OH})_{2}\right]\left[\mathrm{Si}_{3.76} \mathrm{Al}_{0.24} \mathrm{O}_{10}\right] \cdot 2 \mathrm{H}_{2} \mathrm{O}$ [Table $8(a)$ ]. The smectite layer probability (\%S) was $63 \%$ [by equation (3)] with a standard deviation of the mean (SDOM) of $2 \%$. The low $\mathrm{K}$ content [ 0.06 in comparison with 0.31 per $(\mathrm{OH})_{2} \mathrm{O}_{10}$ by equation (1)] and a low interlayer charge [0.43 in comparison with 0.58 per $(\mathrm{OH})_{2} \mathrm{O}_{10}$ by equation (2)] indicate the strong K-deficient and slight charge-deficient character of the sub-type of IS-ml. According to TEM-EDX analyses, 94\% of all measured particles of IS-ml show this $\mathrm{K}$ and charge deficiency [Table 8(a)]. The octahedral sheet was Fe rich.

5.2.2. Di Linh Na-activated bentonite. The Na-activation process increased the number of smectitic layers in the IS-ml phases and decreased the non-smectitic layers in the diVS-ml phases. All KSV-ml phases of the Di Linh reference bentonite dissolved completely, and even quartz was no longer identified in the $<2 \mu \mathrm{m}$ fraction of the Di Linh Na-activated bentonite. The Na-activated material ( $<2 \mu \mathrm{m}$ fraction) was characterized

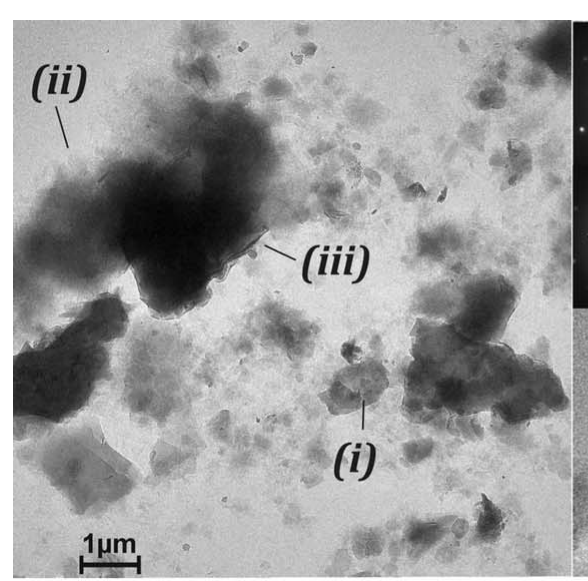

(a)

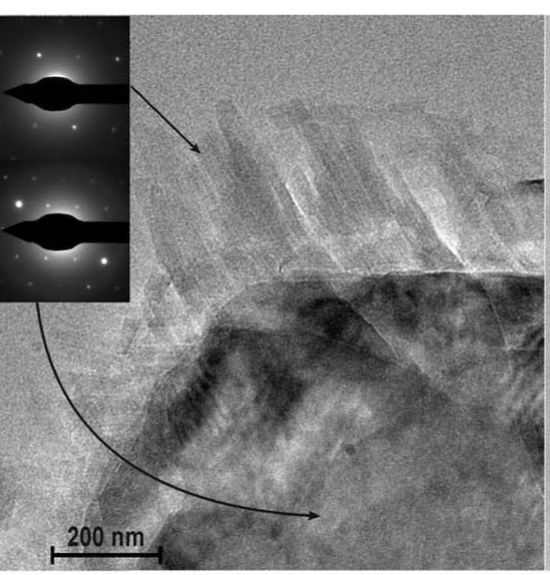

(b)

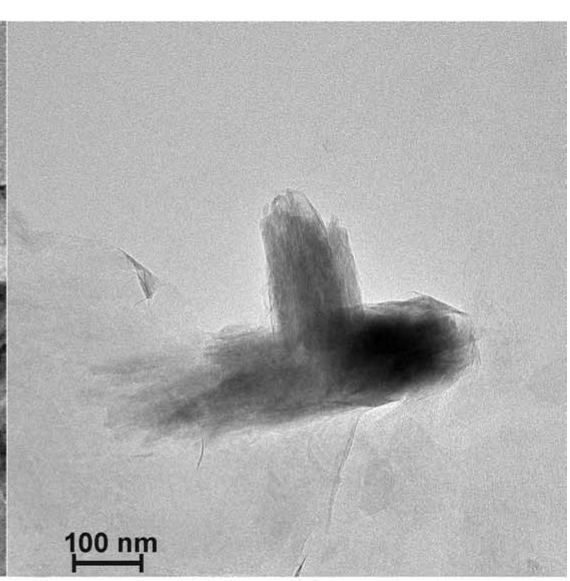

(c)

Figure 5

TEM micrographs of Di Linh bentonite. (a) An overview - particles of illite-smectite interstratifications $(5000 \times)$. (b) Lath-like illite-smectite interstratifications with idiomorphic ends growing at the edges of xenomorphic plates $(43000 \times)$ and SAED images. $(c)$ Goethite $(71000 \times)$. Notes: $(i)$ xenomorphic plates with discrete margins; (ii) cloudy aggregates composed of laths; (iii) aggregates with rolled-up edges. 
Table 8

Structural formulae [average, cations per $(\mathrm{OH})_{2} \mathrm{O}_{10}$ ] of clay minerals in Di Linh bentonite (fraction $\left.<2 \mu \mathrm{m}\right)$, identified by TEM-EDX analyses without further validation by other methods.

\begin{tabular}{|c|c|c|c|c|c|c|c|c|c|c|c|c|c|}
\hline Phase & $\mathrm{Ca}$ & $\mathrm{Mg}$ & $\mathrm{Na}$ & $\mathrm{K}$ & $\mathrm{Al}$ & $\mathrm{Fe}^{3+}$ & $\mathrm{Mg}$ & $\mathrm{Ti}$ & Al & $\mathrm{Si}$ & XII & $n^{\mathrm{VI}}$ & $\% S^{\text {TEM }}$ \\
\hline \multicolumn{14}{|c|}{ (a) Reference material [frequency of occurrence: diVS-ml $/($ diVS-ml + IS-ml $)=94 \%$ ] $\left(n_{\text {meas }}=159\right)$} \\
\hline All 2:1 & 0.05 & 0.07 & 0.11 & 0.08 & 1.39 & 0.41 & 0.19 & 0.00 & 0.24 & 3.76 & 0.44 & 2.00 & $63 \%$ \\
\hline diVS-ml & 0.05 & 0.08 & 0.11 & 0.06 & 1.39 & 0.42 & 0.19 & 0.00 & 0.24 & 3.76 & 0.43 & 2.00 & $63 \%$ \\
\hline IS-ml & 0.03 & 0.03 & 0.09 & 0.36 & 1.40 & 0.34 & 0.22 & 0.00 & 0.24 & 3.76 & 0.56 & 1.97 & $64 \%$ \\
\hline KVS-ml & 0.02 & 0.11 & 0.08 & 0.08 & 2.21 & 0.20 & 0.04 & 0.01 & 0.39 & 3.61 & 0.42 & 2.45 & $\% \mathrm{~K}: \mathrm{S}: \mathrm{V}=23: 22: 55$ \\
\hline \multicolumn{14}{|c|}{ (b) Na-activated material [frequency of occurrence: diVS-ml $/($ diVS-ml + IS-ml $)=97 \%$ ] $\left(n_{\text {meas }}=39\right)$} \\
\hline All 2:1 & 0.03 & 0.18 & 0.09 & 0.14 & 1.47 & 0.34 & 0.19 & 0.00 & 0.51 & 3.49 & 0.66 & 2.00 & $27 \%$ \\
\hline diVS-ml & 0.03 & 0.19 & 0.10 & 0.13 & 1.48 & 0.34 & 0.18 & 0.00 & 0.52 & 3.48 & 0.66 & 2.00 & $26 \%$ \\
\hline IS-ml & 0.00 & 0.17 & 0.00 & 0.17 & 1.31 & 0.34 & 0.36 & 0.00 & 0.18 & 3.82 & 0.53 & 2.00 & $74 \%$ \\
\hline
\end{tabular}

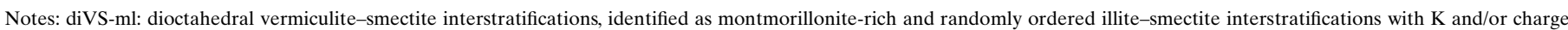

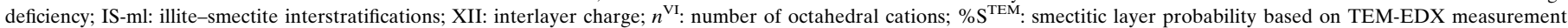
[equation (3)]; $n_{\text {meas }}$ : number of measured particles.

Table 9

Structural parameters of different clay layers of Di Linh bentonite (fraction $<2 \mu \mathrm{m}$ ) obtained by modelling of XRD patterns (oriented specimens) using the Sybilla software.

\begin{tabular}{|c|c|c|c|c|c|c|c|c|c|}
\hline Phase & $\begin{array}{l}\text { Phase content } \\
(\mathrm{wt} \%)\end{array}$ & Sigma star & $\begin{array}{l}T_{\text {mean }} \\
(\mathrm{nm})\end{array}$ & Layer type & $\begin{array}{l}\text { Layer probability } \\
(\%)\end{array}$ & $\begin{array}{l}d \text { spacing } \\
(\mathrm{nm})\end{array}$ & $\begin{array}{l}\text { Interlayer cation } \\
\text { content* }\end{array}$ & $\begin{array}{l}\text { Octahedral iron } \\
\text { content* }\end{array}$ & Gly \\
\hline \multicolumn{10}{|c|}{ (a) Reference material } \\
\hline IS R0 GLY & 64 & 13 & 4.5 & Illite & 10 & 0.992 & 1.92 & 0.00 & \\
\hline \multirow[t]{2}{*}{ IS R1 GLY } & 24 & 17 & 8.3 & Illite & 67 & 0.998 & 1.90 & 0.00 & \\
\hline & & & & Di-smectite 2 gly & 33 & 1.690 & 0.40 & 0.56 & 1.60 \\
\hline Kaolinite & 4 & 6 & 12.4 & Discrete kaolinite & 100 & 0.720 & & & \\
\hline \multicolumn{10}{|c|}{ (b) Na-activated material } \\
\hline \multirow[t]{2}{*}{ IS R0 GLY } & 31 & 11 & 3.6 & Illite & 3 & 0.992 & 1.92 & 0.00 & \\
\hline & & & & Di-smectite 2 gly & 97 & 1.690 & 0.30 & 0.32 & 1.97 \\
\hline \multirow[t]{2}{*}{ IS R1 GLY } & 64 & 32 & 25.2 & Illite & 77 & 0.998 & 1.90 & 0.00 & \\
\hline & & & & Di-smectite 2 gly & 23 & 1.690 & 0.40 & 0.00 & 2.00 \\
\hline Kaolinite & 1 & 4 & 10.3 & Discrete kaolinite & 100 & 0.720 & & & \\
\hline
\end{tabular}

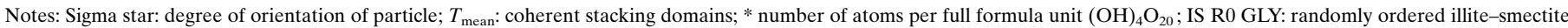
interstratifications in ethylene glycol state; IS R1 GLY: regularly ordered illite-smectite interstratifications in ethylene glycol state; di-smectite 2 gyl: smectite with two glycol complexes.

by diVS-ml with 77 frequency $\%$, IS-ml with 3 frequency $\%$, goethite with 5 frequency $\%$ and CSV-ml with 3 frequency $\%$. The Na-activation process increased the $\mathrm{K}$ and charge deficiency of the diVS-ml phases: a very low $\mathrm{K}$ content $[0.14$ in comparison with 0.65 per $(\mathrm{OH})_{2} \mathrm{O}_{10}$ by equation (1)] and a reduced interlayer charge [0.66 in comparison with 0.76 per $(\mathrm{OH})_{2} \mathrm{O}_{10}$ by equation (2)]. According to TEM-EDX analyses, $97 \%$ of all measured particles of IS-ml show this $\mathrm{K}$ and charge deficiency [Table $8(b)$ ]. The octahedral sheet in smectite was $\mathrm{Fe}$ rich. $\mathrm{Na}$ did not enter the interlayer space and was adsorbed mainly on the surfaces of smectite particles.

\subsection{Validation of TEM-EDX results by XRD data}

5.3.1. Di Linh reference bentonite. IS-ml was identified as the main clay mineral group in the reference bentonite. Small proportions of kaolinite, illite and chlorite were also observed in the XRD pattern [Table $9(a)$ ].
The fitting process of XRD spectra by the Sybilla software demonstrated the existence of two main groups of IS-ml as main clay mineral components of the $<2 \mu \mathrm{m}$ fraction of the Di Linh bentonite [Fig. 6(a) and Table 9(a)]: (i) randomly ordered (Reichweite R0) [IS R0 in Table $9(a)$ ] and (ii) regularly ordered (R1) [IS R1 in Table $9(a)$ ]. These two groups of IS-ml were identified with smectitic layer probabilities of about 90 and 33\%, respectively. The IS-ml phases including IS R0 and IS R1 [Table 9 $(a)$ ] were also characterized by a high amount of $\mathrm{K}$ in illitic layers $\left[\sim 1.92\right.$ per $(\mathrm{OH})_{4} \mathrm{O}_{20}$ which is equal to $\sim 0.95$ per $(\mathrm{OH})_{2} \mathrm{O}_{10}$ ] and a low interlayer charge in smectitic layers [0.33-0.4 per $(\mathrm{OH})_{4} \mathrm{O}_{20}$ or $0.15-0.2$ per $(\mathrm{OH})_{2} \mathrm{O}_{10}$ ]. These two phases from the Sybilla derivations confirmed the charge deficiency recognized as diVS-ml by TEM-EDX identification. However, the Sybilla-derived XRD patterns for IS R0 and IS R1 showed remarkably different octahedral-Fe contents and \%S [Table $9(a)$ ] in comparison with results from TEM-EDX data [Table $8(a)$ ]. The TEM- 
EDX-based octahedral-Fe values were higher and the \%S values lower than those indicated by XRD spectra derived from Sybilla-modelled fitting (octahedral Fe: 0.41 versus 0.21; $\%$ S: 54 versus $75 \%$ ). This situation indicates that some of the Fe measured by TEM-EDX is adsorbed, surrounding the clay particles as an $\mathrm{Fe}$ oxide/hydroxide crust. The Sybilla results for octahedral Fe, therefore, were applied to correct the calculation of structural formula based on TEM-EDX data with the procedure reported by Köster (1977). With regards to the calculation of the new structural formulae, the reduced $\mathrm{Fe}$ amount leads to a lower sum of equivalent charge and an increase of other element values, including $\mathrm{Si}$.

All TEM-EDX data of the diVS-ml particles with \%S between 20 and $69 \%$ [representing the modelled $24 \%$ of IS R1 GLY; Table 9(a)] were averaged and corrected with regard to the octahedral-Fe value obtained by Sybilla modelling of the
IS R1 phase. The same procedure was carried out for all TEMEDX data for diVS-ml particles with \%S higher than $69 \%$ as IS R0 phases. A comparison between structural formulae and morphologies of particles indicated that the cloudy aggregates and randomly ordered diVS-ml were montmorillonite-rich particles; in addition, the xenomorphic plates with discrete edges were illite-rich particles with regular ordering (IS R1). Because of such processing, the $\% \mathrm{~S}$ values based on the TEMEDX data show good agreement with the data from the XRD modelling (Table 10).

5.3.2. Di Linh Na-activated bentonite. Although the Naactivation process of bentonite increased the amount of $\mathrm{Na}$ in the bulk sample, as proved by XRD results (Fig. 3) and XRF results (not shown), this Na effect disappears after the sample has come into contact with water (e.g. separating $<2 \mu \mathrm{m}$ fraction). The similar (001) positions of the XRD patterns of
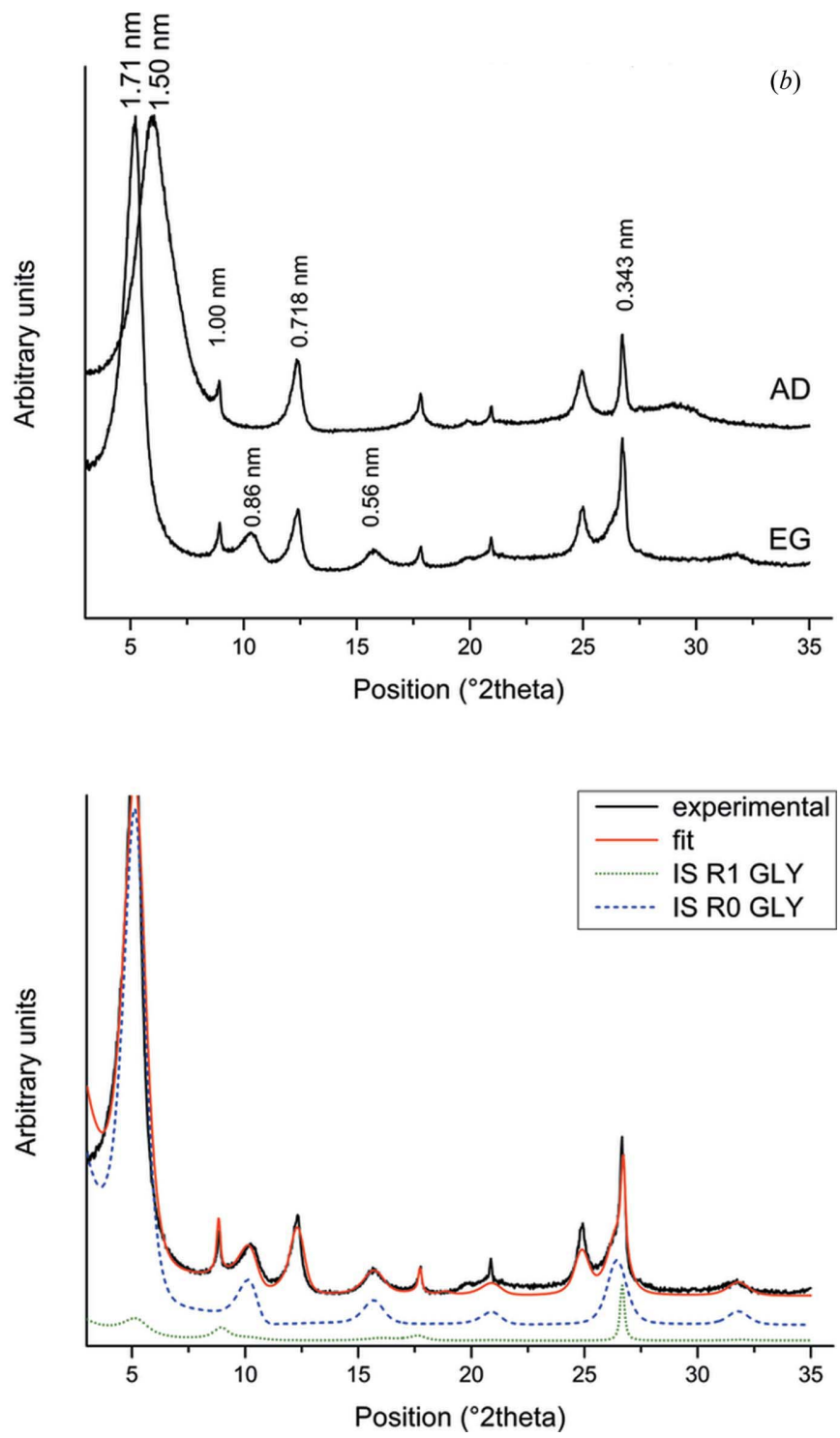

Figure 6

(a)
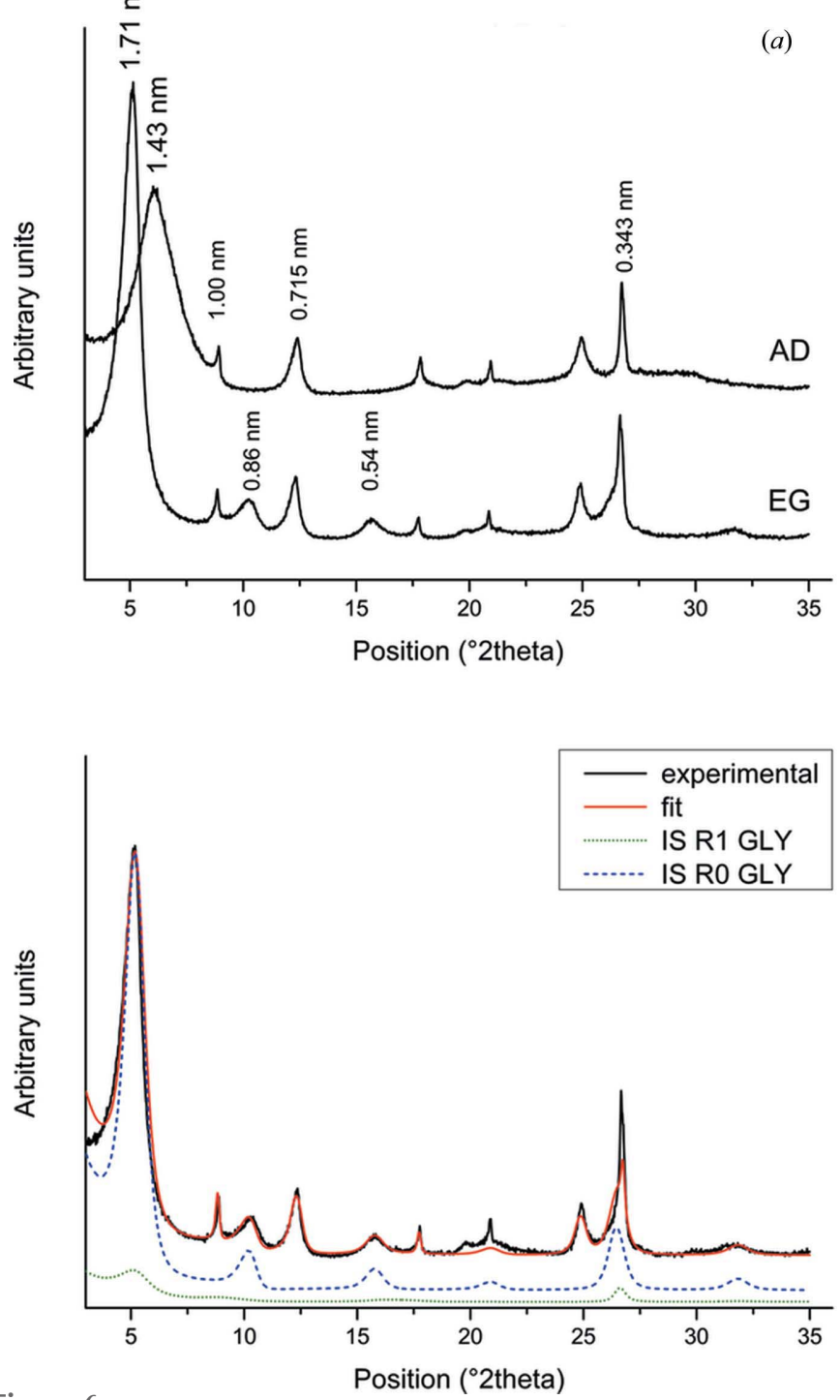

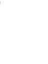


Table 10

Structural formulae [average, cations per $(\mathrm{OH})_{2} \mathrm{O}_{10}$ ] of diVS-ml phase in Di Linh bentonite (fraction $<2 \mu \mathrm{m}$ ), with TEM-EDX data corrected by Sybillabased XRD-pattern modelling with regard to octahedral iron content.

\begin{tabular}{|c|c|c|c|c|c|c|c|c|c|c|c|c|c|c|}
\hline Phase & $\mathrm{Ca}$ & $\mathrm{Mg}$ & $\mathrm{Na}$ & $\mathrm{K}$ & $\mathrm{Al}$ & $\mathrm{Fe}^{3+}$ & $\mathrm{Mg}$ & $\mathrm{Ti}$ & $\mathrm{Al}$ & $\mathrm{Si}$ & XII & $n^{\mathrm{VI}}$ & $\% S^{\text {TEM }}$ & $\% \mathrm{~S}^{\mathrm{XRD}}$ \\
\hline \multicolumn{15}{|c|}{ (a) Reference material } \\
\hline diVS-ml & 0.01 & 0.09 & 0.10 & 0.09 & 1.60 & 0.21 & 0.19 & 0.00 & 0.20 & 3.80 & 0.39 & 2.00 & $71 \%$ & $75 \%$ \\
\hline IS R0 & 0.06 & 0.03 & 0.09 & 0.03 & 1.49 & 0.25 & 0.26 & 0.00 & 0.04 & 3.96 & 0.30 & 2.00 & $91 \%$ & $90 \%$ \\
\hline IS R1 & 0.04 & 0.07 & 0.18 & 0.16 & 1.76 & 0.08 & 0.16 & 0.00 & 0.38 & 3.62 & 0.55 & 2.00 & $34 \%$ & $33 \%$ \\
\hline \multicolumn{15}{|c|}{ (b) Na-activated material } \\
\hline diVS-ml & 0.03 & 0.15 & 0.09 & 0.15 & 1.71 & 0.05 & 0.24 & 0.00 & 0.36 & 3.64 & 0.60 & 2.00 & $46 \%$ & $46 \%$ \\
\hline IS R0 & 0.04 & 0.09 & 0.04 & 0.04 & 1.59 & 0.15 & 0.26 & 0.00 & 0.08 & 3.92 & 0.34 & 2.00 & $93 \%$ & $97 \%$ \\
\hline IS R1 & 0.03 & 0.20 & 0.12 & 0.18 & 1.79 & 0.00 & 0.22 & 0.00 & 0.55 & 3.45 & 0.77 & 2.00 & $22 \%$ & $23 \%$ \\
\hline
\end{tabular}

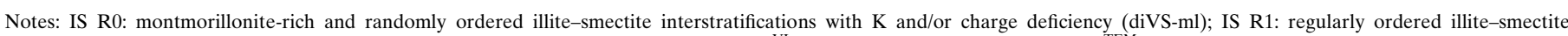

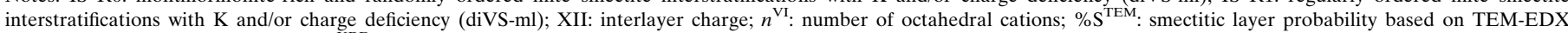
measurement corrected Fe values; $\% \mathrm{~S}^{\mathrm{XRD}}$ : smectitic layer probability based on XRD-pattern modelling by the Sybilla software.

air-dried oriented mounts for two different water systems (Fig. 6), and the composition of the interlayer space (Table 8), visualize this erased effect for material of $<2 \mu \mathrm{m}$ fraction. The amount of $\mathrm{Na}$ in the interlayer space of the Na-activated sample did not change significantly.

The inverse ratio of phase content between IS R0 and IS R1 is the main difference of the Na-activated material in comparison with the reference material (Table 9). The IS R1 phase is the main structure after $\mathrm{Na}$ activation. Furthermore, the IS R1 phase has lost all of its octahedral iron and partially its smectitic layers [Table $9(b)$ ]. The high weight ratio, of $64 \%$, but general low intensity of IS R1 phases [Fig. 6(b)] indicates a high degree of disorder for the IS R1 stacks. The results of Sybilla modelling of the oriented XRD traces allow us to correct the measured TEM-EDX data for identification of structural formulae of the IS R0 and IS R1 phases (Table 10).

\subsection{Role of identification of KSV-ml phase}

The KVS-ml phase (14 frequency \%) was identified only in the original reference bentonite [Table $8(a)$ ]. The dioctahedral vermiculitic layer is the dominating layer type of this phase.
Nearly 20 of all measured particles (159 particles) of the reference bentonite were identified as KSV-ml using equations (4)-(18). An example is reported in Table 6. The probabilities of the three layer types are $25 \%$ kaolinitic layers $(\% \mathrm{~K}), 20 \%$ smectitic layers $(\% \mathrm{~S})$ and $55 \%$ dioctahedral vermiculitic layers $(\% \mathrm{~V})$ on average over these 20 particles. The KSV-ml phases were not identified in the XRD patterns (oriented mounts, $<2 \mu \mathrm{m}$ ). The low frequency and the occurrence of the computed $\mathrm{KSV}$-ml phase only as fine xenomorphic particles in the TEM micrographs leads us to expect a small amount $(<10 \mathrm{wt} \%)$ of this phase in the fraction $<2 \mu \mathrm{m}$ and additionally a low thickness of particles and a higher degree of disorder.

A selected particle was used to analyse a TEM-EDX line profile [Fig. 7(a); see also the zoom in Fig. 5(b)]. The distance from each EDX point to the next one was longer than $150 \mathrm{~nm}$. The maximum diameter of the beam-excited material per measurement point was $\sim 50 \mathrm{~nm}$. The computing of structural formulae for all measured points on this particle results in KSV-ml with diVS-ml phases at the margins of this particle [Fig. 7(b)]. The central part of this particle shows only an

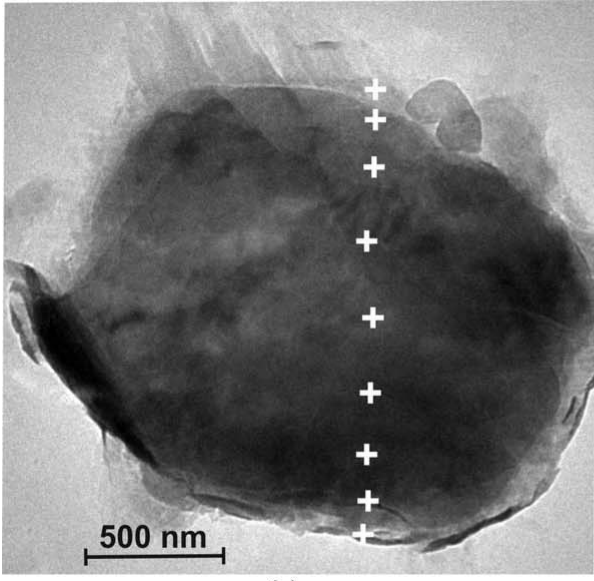

(a)

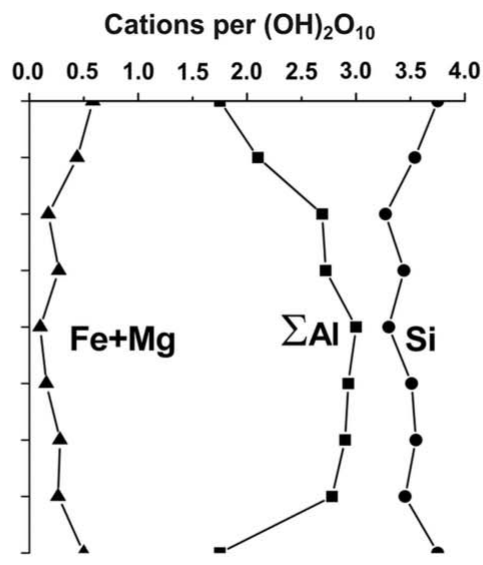

(b)

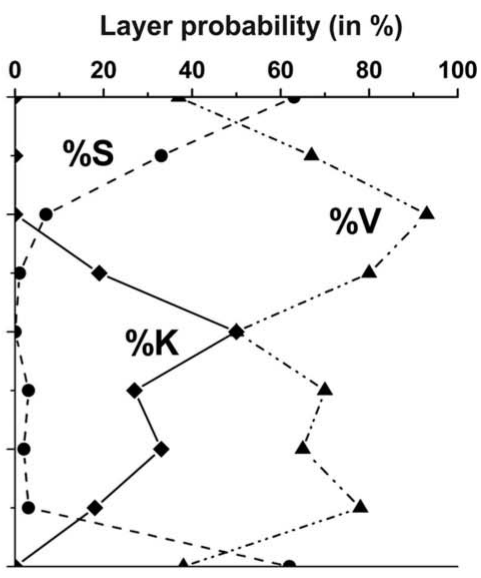

(c)

Figure 7

TEM-EDX line-profile analysis of a selected particle (KSV-ml) of Di Linh reference bentonite. $(a)$ TEM micrograph with EDX measurement points; $(b)$ development of $\mathrm{Fe}+\mathrm{Mg}, \mathrm{Al}_{\text {oct }}+\mathrm{Al}_{\text {tet }}\left(\sum \mathrm{Al}\right)$ and $\mathrm{Si}$ in computed mineral formulae per $(\mathrm{OH})_{2} \mathrm{O}_{10}$, including interpretation as $\mathrm{KSV}$-ml and diVS-ml; $(c)$ development of layers $(\% \mathrm{~K}, \% \mathrm{~S}, \% \mathrm{~V})$ in the measured profile concluded from computed mineral formulae. 
intergrowth of dioctahedral vermiculite and kaolinite [Fig. 7(c)]. From the centre to the edges, the amount of kaolinite is remarkably reduced and dioctahedral vermiculite increases. Smectitic layers are developed directly at the margins of the particle [Fig. 7(c)]. In the TEM micrographs, these diVS-ml phases were observed as laths with idiomorphic ends [Fig. 7(a), upper part of the particle] or as rolled-up margins [Fig. 7(a), lower margin of the particle].

Electron diffraction images [insets in Fig. 5(b)] show that all sheets are oriented in the same crystallographic directions and hence support the interpretation of this particle as a mixedlayer phase. The lack of 'multiple dot' structures in the electron diffraction images excludes here the other general interpretation as a series of individual and overlying particles.

The analysed particle is considered as former detrital muscovite. The intergrowth of kaolinite with dioctahedral vermiculite is a typical weathering process in soil, because muscovite transforms into dioctahedral vermiculite and then into kaolinite. The heating process caused by overlying basalt flow has dissolved the kaolinitic layers at the margins of this large particle. The dissolved material precipitated as diVS-ml phases again at the margins.

The KSV-ml phase could not be identified in the Na-activated material of the Di Linh bentonite. Its absence indicates that the Na-activation process destroyed this sensitive phase. Similar behaviour was also described by Herbert et al. (2004), who studied the activity of clay minerals against some alkaline or acid solutions. The authors proved that during ten days of contact with deionized water (slightly alkalic $\mathrm{pH}$ ) the morphology, stacking order and chemical composition of montmorillonite particles of MX-80 bentonite were altered.

Additionally, the lower FT-IR absorbance intensities of Naactivated material in comparison with the reference bentonite (Fig. 4) indicate an Oswald ripening of particles: dissolution of the finest particles and precipitation by growth into larger stacks.

\section{Conclusions}

A representative set of individual particle analyses for each sample in order to compute structural formulae of clay minerals based on TEM-EDX methodology is a precondition to mirror the variability of different clay minerals and the different geological or technical processing signals in their composition. The described method of chemical formula computation and interpretation of possible clay mineral species for each measured point is suitable for various structures, including 1:1, 2:1 and 2:1:1 types of clay minerals as well as their interstratifications with two and three members.

A validation of the actual occurrence of the computed mixed-layer phases in the samples is recommended, by electron diffraction (to distinguish between intergrowth or overlapping particles), by TEM-EDX measurements of statistically sufficient numbers of particles per sample and by modelling of oriented XRD patterns. HR-TEM offers a further opportunity to identify directly in the sample those computed mixed-layer phases.
A clay like the Di Linh bentonite contains a high amount of Fe precipitated on the surface of clay particles and/or included in their individual crystals. Usually, the dithionite treatment (Mehra \& Jackson, 1958) can be applied as a standard method for removing discrete Fe minerals and surface-adsorbed Fe compounds. However, this chemical pretreatment can cause some modification of the structural formula of sensitive clay particles. In this case, the modelling of XRD patterns (oriented mounts) using the Sybilla software appears to be a practical way of correcting measured TEM-EDX results, especially concerning the Fe content. Therefore, the combination of TEM-EDX and XRD methods clearly offers a tool for identifying every structural formula of a single clay mineral.

The combination of TEM-EDX and XRD methods was applied successfully to identify in detail the mineral composition of the Di Linh reference bentonite. Its main component is $\mathrm{K}$ - and charge-deficient illite-smectite interstratifications (or diVS-ml) including both IS R0 and IS R1 structures (Table 9). The technique also proved that the Na activation of this bentonite dissolved some parts of the montmorilloniterich interstratifications (see IS R0-phases in Table 9), reduced the number of smectitic layers (illitization) and destroyed all KSV-ml particles.

A TEM-EDX line profile through one large particle (KSV$\mathrm{ml}$ ) has revealed also a part of the weathering history and the impact of heat arising from overlying basalt flows. The core of the investigated particle, a kaolinite-muscovite intergrowth, has shown an alteration at the margins of KSV-ml into diVS-ml (Fig. 7).

\section{APPENDIX $A$}

Excel routine for computing mineral formulae of clay minerals from TEM-EDX measurements

The Excel routine introduced in this report is free to use for testing and sharing (https://drive.google.com/open?id= 1WM7705ln5WgNPNMO1d76gGqrzDWYw5MW), but users are requested to cite this publication if results generated with this routine are published in any form. In case of any questions in the handling of this routine, users are invited to contact the authors at the listed e-mail address.

\section{Acknowledgements}

The authors would like to thank Mr Nguyen An Thái, Mr Đang Ngoc Hai, and staff of Lam Dong Minerals and Building Materials Joint Stock Company-Hiep Phu Joint Stock Company for their support during the field trip and while collecting material of the Di Linh bentonite. We also thank two anonymous reviewers for their suggestion and evaluation.

\section{Funding information}

This research is funded by the Vietnam National Foundation for Science and Technology Development (NAFOSTED) under grant No. 105.99-2015.30. 


\section{References}

Aplin, A. C., Matenaar, I. F., McCarty, D. K. \& van der Pluijm, B. A. (2006). Clays Clay Miner. 54, 500-514.

Badaut, D., Decarreau, A. \& Besson, G. (1992). Clay Miner. 27, $227-$ 244.

Bain, D. C., McHardy, W. J. \& Lachowski, E. E. (1994). Clay Mineralogy: Spectroscopic and Chemical Determinative Methods, edited by M. J. Wilson, pp. 260-299. London: Chapman \& Hall.

Bergmann, J., Friedel, P. \& Kleeberg, R. (1998). CPD Newsl. 20, $5-8$.

Berthonneau, J., Grauby, O., Ferrage, E., Vallet, J.-M., Bromblet, P., Dessandier, D., Chaudanson, D. \& Baronnet, A. (2014). Eur. J. Mineral. 26, 643-656.

Brindley, G. W. (1982). Clays Clay Miner. 30, 153-155.

Champness, P. E. (1997). Adv. Imag. Elect. Phys. 101, 1-36.

Cliff, G. \& Lorimer, G. W. (1975). J. Microsc. 103, 203-207.

Crâciun, C. (1984). Spectrosc. Lett. 17, 579-590.

De la Calle, C. \& Suquet, H. (1988). Hydrous Phyllosilicates (Exclusive of Micas), Reviews in Mineralogy, Vol. 19, edited by S. W. Bailey, pp. 455-496. Washington, DC: Mineralogical Society of America.

DGM (1999). Geology and Mineral Resources Map (1:200 000), Da Lat - Cam Ranh sheet (C-49-I \& C-49-II). Department of Geology and Minerals of Viet Nam.

Doebelin, N. \& Kleeberg, R. (2015). J. Appl. Cryst. 48, 1573-1580.

Drief, A., Martinez-Ruiz, F., Nieto, F. \& Sanchez, N. (2002). Clays Clay Miner. 50, 746-756.

Drits, V. A., Sakharov, B. A., Lindgreen, H. \& Salyn, A. (1997). Clay Miner. 32, 351-371.

Eggleton, R. A. (1977). Clay Miner. 12, 181-194.

Eggleton, R. A. \& Tilley, D. B. (1998). Clays Clay Miner. 46, 400-413.

Elsass, F. (2006). Handbook of Clay Science, Developments in Clay Science, Vol. 1, edited by F. Bergaya, B. K. G. Theng \& G. Lagaly, pp. 939-963. Oxford: Elsevier.

Emmerich, K. \& Kahr, G. (1998). Ber. Dtsch. Ton- Tonmineralgruppe, 6, 1-15.

Farmer, V. C. (1974). Editor. The Infrared Spectra of Minerals, Monograph 4. London: Mineralogical Society.

Farmer, V. C. \& Russell, J. D. (1964). Spectrochim. Acta, 20, 11491173.

Galán, E. \& Carretero, I. (1999). Clays Clay Miner. 47, 399-409.

Galán, E. \& Ferrell, R. E. (2013). Handbook of Clay Science, Developments in Clay Science, Vol. 5A, edited by F. Bergaya \& G. Lagaly, pp. 83-126. Oxford: Elsevier.

García-Romero, E., Suárez Barrios, M. \& Bustillo Reyuelta, M. A. (2004). Clays Clay Miner. 54, 484-494.

Gaudin, A., Dehouck, E., Grauby, O. \& Mangold, N. (2018). Icarus, 311, 210-223.

Goodman, B. A., Russell, J. D., Fraser, A. R. \& Woodhams, F. W. D. (1976). Clays Clay Miner. 24, 52-59.

Graf von Reichenbach, H. \& Beyer, J. (1997). Clay Miner. 32, 573586.

Hai, L. C. (1979). Report of Characteristics of Benonite in Di Linh Area. Vietnam Institute of Geosciences and Mineral Resources, Department of Geology and Minerals of Vietnam.

Henning, K.-H. \& Helmchen, H. (1967). Dtsch. Ges. Geologischer Wissenschaft B, 12, 195-199.

Henning, K.-H. \& Störr, M. (1986). Electron Micrographs (TEM, SEM) of Clays and Clay Minerals, p. 325. Akademie-Verlag Berlin.

Herbert, H. J., Kasbohm, J., Moog, H. C. \& Henning, K. H. (2004). Appl. Clay Sci. 26, 275-291.

Herbert, H. J., Kasbohm, J., Nguyen, T. L., Meyer, L., Hoang, T. M. T. \& Xie, M. (2011). (GRS 295) Fe-bentonite - Experiments and Modeling of the Interactions of Bentonites With Iron, p. 292. Gesellschaft für Anlagen- und Reaktorsicherheit.

Herbert, H. J., Kasbohm, J., Sprenger, H., Fernández, A. M. \& Reichelt, C. (2008). Phys. Chem. Earth Parts ABC, 33, S327-S342.
Hoang-Minh, T., Nguyen-Thanh, L., Nguyen, T.-D., Nguyen, D.-T., Lai, L. T., Thuyet, N. T. M., Kasbohm, J., Pusch, R. \& Knutsson, S. (2014). Proceedings of the 13th International Symposium on Mineral Exploration, Hanoi, pp. 143-148. Hanoi: Vietnam National University Press.

Hong, H., Cheng, F., Yin, K., Churchman, G. J. \& Wang, C. (2015). Am. Mineral. 100, 1883-1891.

Huy, D. S. (1982). Report of Research in Details About Tam Bo Bentonite - Di Linh - Lam Dong. Department of Geology and Minerals of Vietnam.

Johns, W. D. \& Gier, S. (1998). Berichte der DTTG, Band 6, pp. 98 104. Deutsche Ton- und Tonmineralgruppe.

Joswig, W. \& Fuess, H. (1989). Clays Clay Miner. 37, 216-218.

Kasbohm, J., Tarrah, J. \& Henning, K.-H. (2002). Berichte der DTTG, Band 9, pp. 71-84. Deutsche Ton- und Tonmineralgruppe.

Kogure, T. \& Banfield, F. J. (1998). Am. Mineral. 83, 925-930.

Kogure, T., Hybler, J., Ďurovič, S. (2001). Clays Clay Miner. 49, 310317.

Köster, H. M. (1977). Clay Miner. 12, 45-54.

Köster, H. M. (1981). Proceedings of the International Clay Conference. Amsterdam, New York: Elsevier.

Lorimer, G. W. \& Cliff, G. (1976). Electron Microscopy in Mineralogy, edited by H. R. Wenk, pp. 506-519. Berlin: Springer Verlag.

Madejová, J. \& Komadel, P (2001). Clays Clay Miner. 49, 410432.

Madejová, J., Komadel, P. \& Č́čel, B. (1994). Clay Miner. 29, 319 326.

Madsen, F. T. (1998). Clay Miner. 33, 109-129.

Mehra, O. P. \& Jackson, M. L. (1958). Clays Clay Miner. 7, $317-$ 327.

Meissner, E., Sharp, T. G. \& Chakraborty, S. (1998). Am. Mineral. 83, 546-552.

Mellini, M. \& Menichini, R. (1985). R. Soc. Ital. Miner. Petrol. 40, 261-266.

Meunier, A. \& Velde, B. (1989). Am. Mineral. 74, 1106-1112.

Moore, D. E. \& Reynolds, R. C. (1997). X-ray Diffraction and the Identification and Analysis of Clay Minerals, 2nd ed., p. 400. London: Oxford University Press.

Nadeau, P. H. (1998). Clays Clay Miner. 46, 18-26.

Newman, A. C. D. \& Brown, G. (1987). Chemistry of Clays and Clay Minerals, Mineralogical Society Monograph, 6, pp. 1-128. Harlow: Longman Technical and Scientific.

Nguyen-Thanh, L. (2012). PhD thesis, Ernst-Moritz-Arndt-University Greifswald, Germany.

Nguyen-Thanh, L., Herbert, H.-J., Kasbohm, J., Hoang-Minh, T. \& Mählmann, R. F. (2014). Clays Clay Miner. 62, 425-446.

Nguyen-Thanh, L., Hoang-Minh, T., Herbert, H. J., Kasbohm, J., Lai, L. T., Nguyen, N. M. \& Mählmann, R. F. (2017). Geoderma, 308, 159-170.

Nguyen-Thanh, L., Hoang-Minh, T., Kasbohm, J., Herbert, H. J., Nguyen Thuy, D. \& Le Thi, L. (2014). Appl. Clay Sci. 101, 168176.

Nguyen-Thanh, L., Kasbohm, J. \& Hoang-Minh, T. (2010). Abstract Series of the 5th Mid-European Clay Conference, 756, Department of Mineralogy, Geochemistry and Petrology, University of Szeged, Budapest.

Pusch, R., Kasbohm, R., Hoang-Minh, T., Knutsson, S. \& NguyenThanh, L. (2015). Eng. Geol. 188, 28-47.

Rieder, M., Cavazzini, G., Dýakonov, Y. S., Frank-Kamenetskii, V. A., Gottardi, G., Guggenheim, S., Koval, P. V., Muller, G., Neiva, A. M. R., Radoslovich, E. W., Robert, J. L., Sassi, F. P., Takeda, H., Weiss, Z. \& Wones, D. R. (1998). Can. Mineral. 36, $905-$ 912.

Rosenberg, P. E. (2002). Am. Mineral. 87, 103-107.

Russell, J. D., Farmer, V. C. \& Velde, B. (1970). Miner. Mag. 37, 869879.

Sakharov, B., Lindgreen, H., Salyn, A. \& Drits, V. A. (1999). Clay Miner. 34, 333-344. 
Shirozu, H. \& Bailey, S. W. (1965). Am. Mineral. 50, 868-885.

Środoń, J., Elsass, F., McHardy, W. J. \& Morgan, D. J. (1992). Clay Miner. 27, 137-158.

Szymanski, R., Loeber, L. \& Durand, C. (1990). Proceedings of the 9th International Clay Conference, Strasbourg, pp. 149-158. Strasbourg: Institut de Géologie-Université Louis-Pasteur.

Tamrat, W. Z., Rose, J., Grauby, O., Doelsch, E., Levard, C., Chaurand, P. \& Basile-Doelsch, I. (2018). Geochim. Cosmochim. Acta, 229, 53-64.

Torres-Ruíz, J., López-Galindo, A., González-López, J. M. \& Delgado, A. (1994). Chem. Geol. 112, 221-245.

Ufer, K., Roth, G., Kleeberg, R., Stanjek, H., Dohrmann, R. \& Bergmann, J. (2004). Z. Kristallogr. 219, 519-527.
Ufer, K., Stanjek, H., Roth, G., Dohrmann, R., Kleeberg, R. \& Kaufhold, S. (2008). Clays Clay Miner. 56, 272-282.

Vicente, M. A., Elsass, F., Molina, E. \& Robert, M. (1997). Clay Miner. 32, 435-451.

Warren, E. A. \& Curtis, C. D. (1989). Clay Miner. 24, 137-156.

Weir, A. H. (1965). Clay Miner. 6, 17-22.

Wiewóra, A. (1990). Clay Miner. 25, 93-98.

Wilson, J., Savage, D., Bond, A., Watson, S., Pusch, R. \& Bennett, D. (2011). Bentonite - A Review of Key Properties, Processes and Issues for Consideration in the UK Context. Report. Quintessa Ltd, Henley-on-Thames, UK.

Zöller, M. H. (1993). Berichte der DTTG, Band 2, pp. 211-220. Deutsche Ton- und Tonmineralgruppe. 